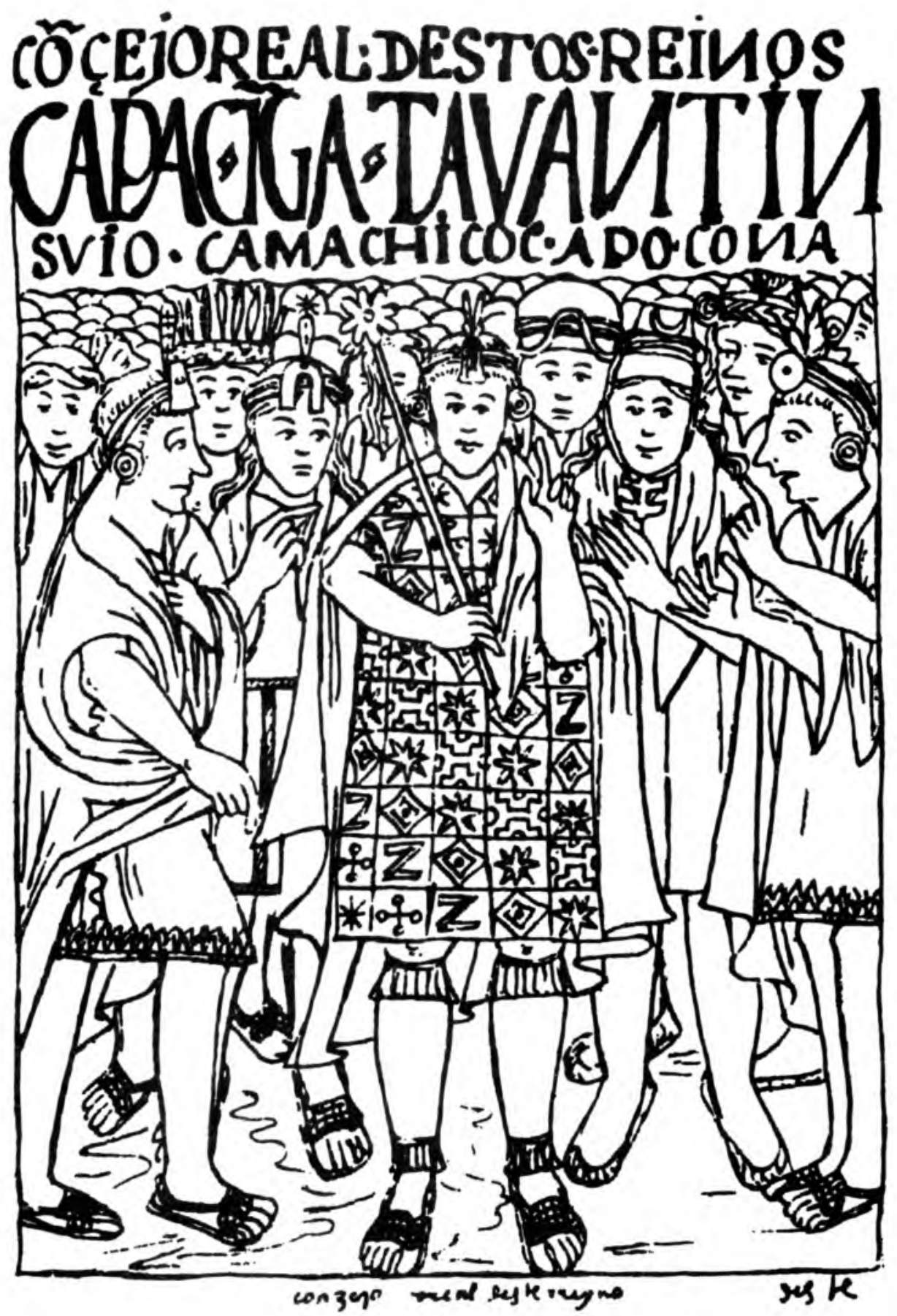

Figura 1. Dibujo que representa los grupos étnicos que conformaban el Tawantinsuyu con sus propias vestimentas (Guamán Poma de Ayala 1993 [1616]) 


\title{
Valoración minero-metalúrgica circumpuneña: Menas y mineros para el Inka rey
}

LAUTARo NúÑ̃EZ A. ${ }^{1}$

\author{
'De cerro Negro pa' lla' \\ tenían plata \\ enterrado los Gentiles. \\ $Y$ después vinieron los Reinkas. \\ Dicen que trajinaban \\ a los Reinkas en andas" \\ (Anónimo de Toconce, \\ Castro y Varela 1998)
}

\section{RESUMEN}

Se destacan los logros tecnológicos minero-metalúrgicos del Area Centro Sur Andina obtenidos a través de un proceso de especialización creciente controlado por las élites antes y durante el régimen incaico. En este escenario, la Subárea Circumpuneña habría alcanzado en etapas pre incaicas altos niveles de especialización y productividad minera movilizada a través del tráfico de bienes y materias primas de estatus, constituyendo el principal estímulo para la emergencia de identidad iconográfica, poder y autonomía políti$\mathrm{ca}$, independiente de los excedentes agropecuarios limitados a ambientes desérticos. La movilidad de bienes de estatus a través de redes de complementariedad desde los oasis de Atacama, río Loa, y el litoral, hizo propicio el acceso y recepción de ideas y bienes multiétnicos provenientes de las áreas vecinas, creando las condiciones para la consolidación de vías locales de desarrollo complejo en el borde suroeste del área.

1 Instituto de Investigaciones Arqueológicas y Museo, R. P. Gustavo Le Paige S. J., Universidad Católica del Norte, San Pedro de Atacama. Email: lautaronunez@hotmail.com
Hacia estos distritos mineros y sus redes de interacción preexistentes, se condujo la expansión inca meridional a través de un dominio directo orientado a la organización de mitas extractivas pactadas con las élites locales incanizadas, en cuyo propósito se advierte el aprovechamiento de mano de obra local especializada y experimentada en el manejo de los recursos mineros, sin enfatizar la circulación de bienes culturales cuzqueños y fuerza de trabajo foránea.

Para apoyar esta propuesta se documenta el registro poco común de sitios mineros localizados en espacios inhóspitos o alejados de los locis aldeanos, caracterizados por campamentos, labores y rutas, más alejados del tramo clásico del así llamado Camino del Inca. En este sentido, la hipótesis orientada a explicar la expansión inca hacia los distritos mineros, reconocida en la literatura regional, cobra mayor significado con evidencias provenientes de contextos laborales inca-locales.

\section{ABSTRACT}

The technological mining-metallurgic achievements of the Andean Center South Area are stood out through a process of growing specialization controlled by the elites before and during the inca 
regime. In this scene, the Subarea that surrounds the Puna reached high levels of specialization and mining productivity moved through the traffic of goods and raw material of status, establishing the main stimulus for the emergency of iconographic identity, power and political autonomy, independent from the agricultural surplus limited to desertic environment. The mobility of items of status through the complementarity nets from the coast and the oasis of Atacama and Loa river, established the access and reception of ideas and multiethnic goods, coming from the andean diversity of the boundaries, creating the conditions for the consolidation of local complex development in the rim of the south-west of the area.

Towards these mining districts and their interaction nets, the southern inca expansion was directed through the dominion oriented to the extractive mitas stipulated with the local elites, assimilated inca patterns, where the improvement of the local working force specialized and experienced in the manage of mining resources is observed as a proposal, without over emphatized the circulation of cultural goods from Cuzco and the foreign working force.

To ratify this proposal the register not common of mining sites located in the empty and far spaces of the town are documented; characterized by the camps sites, labours and routes; this time faraway from the classic path, the so called Inca's road. In this sense, the hypothesis to explain the inca expansion in the mining districts which surrounds the Puna, recognized in the regional literature, has more significance with evidences coming from inca-local working contexts.

\section{Importancia de la producción minero-metalúr- gica en los Andes Centro-Sur}

Los estudios paleometalúrgicos han vinculado tecnología con complejidad social en términos de que el surgimiento de especialización y su impacto social, político e ideológico, llegó a ser un componente fundamental en los procesos civilizatorios (Childe 1954). Sin embargo, al contrario de lo sucedido en Europa, los objetos metálicos en los Andes estaban dirigidos a sustentar ideologías más que medios de producción, en cuanto por ellos se accedía al poder basado en la ritualización de las acciones cotidianas y jerárquicas. Así, el discurso del poder pasaba por las imágenes de los objetos metálicos por su forma, brillo, tamaño, disposición y color, marcando las diferencias entre dominantes y dominados.

Se ha aceptado que la tradición metalúrgica en los Andes Centrales es la más antigua de la América Andina (Lechtman 1980), encontrándose los hallazgos más tempranos en Chavín y Cupisquinique. Sin embargo, el proceso parece ser más antiguo puesto que discos de cobre de contextos funerarios Cupisnique han sido datados entre 1500 y 1300 AC (Elera y Pinilla 1990), lo que significa que tanto en los Andes Centrales como en los Septentrionales las evidencias de cobre se constatarían hacia fines del segundo milenio AC (Shimada 1994).

Por otro lado, en el Valle del Lurín (Perú), se han registrado artefactos de cobre y oro datados por los $1050 \mathrm{AC}$, donde el cobre nativo precede a la producción de cobre fundido (Burger et al. 1998), a pesar de que el rol del primero parecía ser poco relevante dada su carencia en los Andes Centrales (Lechtman 1988). Esta excelencia de la producción metalúrgica no ha permitido esclarecer el rol de los distritos mineros de los Andes Centro Sur, donde la evidencia más antigua de cobre fundido provino de Wankarani, en el Altiplano Meridional, y se dató por los 1200 AC (Ponce 1970). No obstante, se había supuesto que por esta época ya existían explotaciones de mineral sulfatado (brochantita y antlerita) en el desierto chileno, que se habría traficado desde las tierras bajas áridas al altiplano, localizándose en Chiripa por los 12001000 AC (Browman 1991, Lechtman 1980, Núñez 1987).

Recientes estudios en la aldea de Ramaditas demostraron que hay evidencias de cobre fundido datado por los $50 \mathrm{AC}$, con apoyo agrario local, en el cual el rol de los bosques de Prosopis sp. fue importante asociado a brochantita y antlerita, componentes típicos del ambiente hiperárido del norte de Chile (Graffam et al. 1994). No obstante, aún cuando su registro es posterior a Chiripa, se admite que la producción de cobre en la circumpuna de Atacama formó parte de un temprano y singular tráfico de metales en el área 
(Núñez 1987). Al respecto, recientes investigaciones han indicado que desde $1200 \mathrm{AC}$ las comunidades pastoralistas de la fase formativa temprana Tilocalar (1200-500 AC) ya presentan un modelo aldeano complejo con actividades permanentes basadas en la producción de carne y horticultura, junto a los primeros cementerios concentrados, con registro de piezas martilladas de cobre y oro. $\mathrm{Al}$ respecto, en enterramientos de párvulos se hallaron dos láminas de oro con la imagen de un rostro humano radiado prolongado en sierpe, láminas rectangulares y una cuchara de cobre, relacionados a grandes martillos asociados a fragmentos de mineral de cobre. Estas evidencias señalan que cobre y oro fueron tratados con técnicas de repujado, golpeado y laminado, constituyendo por ahora uno de los primeros íconos metálicos del Area Centro Sur Andina. En consecuencia, los registros de la fase Tilocalar son tan tempranos como los de los Andes Nucleares, demostrando que las tradiciones minero-metalúrgicas de la circumpuna de Atacama y Altiplano Meridional son independientes y provienen de experiencias formativas antiguas con especializaciones de oficios en contextos pastoralistas (Núñez 1992).

Para momentos posteriores, Graffam (1996 Ms) estudió contextos funerarios del Periodo Medio de San Pedro de Atacama, observando que las hachas en " $T$ " comunes en las fases Sequitor, Quitor y Solor (100-1200 DC) indican una relación ternaria de arsénico, níquel y cobre. Estos implementos son frecuentes en esta zona teniendo un carácter más intrusivo en el altiplano, por lo que es factible aceptar que estas aleaciones se producían en Atacama. Precisamente, el sitio Casa Parroquial arrojó una alta frecuencia de implementos en metal, incluyendo vasos-retratos Tiwanaku, destacando el rol de los recursos locales y de los especialistas para lograr una producción de prestigio panandino (Téllez $1998 \mathrm{Ms}$ ).

Además, los estudios locales han señalado que el cobre proveniente de Chuquicamata u otras menas más cercanas a San Pedro, era rico en arsénico, enargita y sus derivaciones alteradas y secundarias como la chenevixita (Núñez 1987, Lechtman 1980), todo lo cual fue traficado hacia Tiwanaku tanto en estado mineral como fundido (lingotes), con alto contenido arsenical, constituyendo en parte lo que ahora se reconoce como bronce arsenical (Lechtman 1997).

Paralelamente a la interacción entre Tiwanaku y la circumpuna, en el N.O. Argentino se desarrollaron en el Valle del Hualfín, las fases Ciénaga y Aguada (500-1200 DC) en las que son característicos ciertos objetos de estatus o cotidianos como: hachas, punzones, cinceles, cuñas, agujas, brazaletes y pinzas, fundidos en bronce-arsénico y estaño sin níquel (A.R. González 1979, Foster 1962). Esta combinación, en términos de ausencia y/o presencia de níquel o estaño es sustancial para determinar procedencia, contactos y flujos de tecnologías, siendo importante identificar las menas responsables de cobre-arsénico-níquel y/o cobrearsénico-estaño. De hecho, la presencia de barritas de estaño en contextos funerarios de San Pedro de Atacama señala un tráfico de retorno de recursos ausentes en la vertiente occidental.

Posteriormente, con la fase Quitor (400-700 DC) se inicia una mayor jerarquización y complejidad social, junto a una notable relación extra territorial con las Subáreas Circumtiticaca y Altiplano Meridional. Las relaciones con Tiwanaku alcanzaron las esferas socioeconómicas y religiosas reflejadas en una maestría local que involucró a todas las artes aplicadas en iconos compartidos a nivel macro espacial, como los vasos-retratos de oro repujado y el uso de piedras preciosas en implementos de madera. Precisamente, Le Paige (Ms) registró en el cementerio Coyo Oriental 40 martillos en 33 sepulturas con influencia Tiwanaku, en una de las cuales se halló una bolsa con mineral de cobre, datada en 577 años DC, contemporánea con la colonia minera de Chuquicamata fechada entre los 500-700 DC (Costa y Llagostera 1994, Bird 1987 y 1979). Puesto que las colonias implican el retorno a sus núcleos, hasta ahora no se han registrado áreas funerarias en los asentamientos vinculados con los sectores extractivos. Por lo mismo, en los cementerios de los ayllos, como Coyo Oriental, se han identificado cuerpos con signos de artritis a raíz de la intensificación de las labores de extracción y carga pesada (Arriaza $1990 \mathrm{Ms}$ ).

Durante Tiwanaku la producción de bronce arsenical empleó cuatro tipos de cobre y aleaciones: cobre impuro, cobre arsenical, una aleación de cobre, arsénico y níquel y bronce estañífero 
(Lechtman 1980, 1997). Llama la atención el temprano manejo de un patrón de aleación singular: cobre, arsénico y níquel desde los $600 \mathrm{DC}$, hasta 1100 DC, usado tanto para herramientas (p.e. grapas) como para objetos de ornato y estatus (p.e. topus) (Lechtman 1997). El bronce es el resultado de la combinación cobre-arsénico y/o cobre-estaño y su uso en los Andes fue un logro posterior a las combinaciones cobre-plata y cobre-oro. El uso de menas con cobre-arsénico y en consecuencia, la producción de bronce arsenical a gran escala marca un indicador relevante del Horizonte $\mathrm{Me}$ dio. Efectivamente, las aleaciones de cobre y arsénico fueron utilizadas ampliamente desde los 850 DC hasta el Período Tardío en los Andes Centrales (Lechtman 1988, 1997). En este sentido, el análisis de grapas o puentes metálicos con la aleación cobre, arsénico y níquel para unir los bloques de rocas canteadas en los monumentos de Tiwanaku, significa que disponían de abundantes recursos para aplicar esta tecnología de ensamble. No obstante, se acepta que los recursos trasladados de los depósitos de porfido/enargita del desierto de Atacama o los del litoral del desierto (p.e. níquel) tendrían propiedades valoradas en el exterior, con esto, la presencia de cobre de Atacama en contextos Tiwanaku (Lechtman, com. pers. 1999) apoya el tráfico caravanero de metales tal como se había planteado preliminarmente (Núñez 1987).

Con la hegemonía Tiwanaku, la actividad minero-metalúrgica local alcanzó un alto grado de perfeccionamiento cualitativo y acrecentó la producción entre otros de objetos de uso doméstico (cucharas, pinzas, cinceles, mazas), ornamentos (cintillos, aros, placas cailles, brazaletes, topus, pectorales, tocados), rituales (vasos libatorios, cascabeles, campanillas) y de prestigio (hachas), confeccionados en cobre, oro, plata, estaño y plomo además de sus respectivas aleaciones (Tarragó y González 1988 y 1979, Núñez 1992, Lechtman 1984, Lechtman y González 1991). Esta singular situación que se viene anunciando desde momentos formativos, contrasta con aquella observada en los Valles Occidentales de Arica donde las colecciones metalúrgicas son más restringidas.

Luego, en tiempos post Tiwanaku se fortalecieron los señoríos regionales locales y aledaños, si-. tuándose el tráfico de metales y piedras preciosas bajo el control más estricto de las jefaturas. El uso de implementos emblemáticos se redujo a los miembros de la elite, disminuyendo en la vida cotidiana y en la mayoría de los contextos funerarios, a raíz del incremento del tráfico de lingotes y piedras preciosas al exterior. Efectivamente, durante el Período del Desarrollo Regional Avanzado los cementerios san pedrinos no presentan ofrendas sofisticadas, incluyendo hachas sin hojas metálicas o reemplazadas por piezas de hueso, collares toscos de rocas ordinarias que reemplazan a las cuentas de azuritas, malaquitas y turquesas, comunes en etapas previas. La elite controlaba la producción y usaba las piezas metálicas del poder, como lo demuestra el entierro aislado de un personaje Yavi en el ayllo de Conde Duque con una muñequera de plata y hacha de cobre con gancho del clásico modelo trasandino (Núñez 1994 Ms).

La emergencia de complejidad y el acceso creciente a recursos de estatus tiene que ver con nociones de crecimiento y división de la sociedad en estamentos diferenciados, to cual conduce a recursos materiales y sociales de un modo asimétrico (Brumfield 1995). Tal proceso se identifica en el Area Centro-Sur con sociedades complejas y pre estatales, cuyas jefaturas establecían relaciones de explotación a partir del manejo del trabajo obligatorio de los dominados (bienes de excedentes). La producción especializada de metales es parte de esta hegemonía política y religiosa de la élite sur andina orientada a crear riqueza y simbolismo para la consolidación del poder (Clark y Parry 1991).

Por otra parte, la localización de los oasis atacameños en el centro de las conexiones entre los ambientes altiplánicos, yungas, oasis piemontanos y costa, permitió organizar y administrar el movimiento de bienes desde la vertiente occidental hacia los enclaves trasandinos, y viceversa, a través de alianzas caravánicas de larga distancia (Núñez y Dillehay 1979). En este escenario es fácil comprender la relación de estos oasis con la producción y circulación especializada de minerales, metales fundidos, rocas preciosas y conchas del Pacífico, entre otros bienes. La baja producción excedentaria agraria y pecuaria comparada con el mayor hectareaje de otros valles del área, si bien fue traficada al exterior aledaño, sustentó el 
alto rendimiento de fuerza de trabajo especializada en la producción y circulación de bienes de estatus en donde los metales tuvieron un rol significativo (Núñez 1992).

En suma, con los antecedentes presentados se puede advertir que en las cuencas de Atacama y del Loa, las actividades minero-metalúrgicas tienen un curso evolutivo de unos 2500 años de experiencia anteriores a los incas, lo que resulta fundamental para entender el escenario al tiempo de la expansión del Tawantinsuyu. Además, la localización del territorio atacameño en el distrito más mineralizado del país, condicionó su explotación desde el Formativo Temprano, conformando uno o el locus más antiguo de explotación minerometalúrgico de los Andes del Sur (Núñez 1992).

Las "firmas" de trazas isotópicas para el rastreo del tráfico, indican que no toda la población del Area Centro Sur Andina tuvo acceso directo a los recursos mineros más competitivos, siendo el movimiento de bienes y tecnologías el que diseminó los especimenes o materiales hacia regiones deficitarias. Pero en Atacama, las colonias mineras, los talleres de fundición y los orfebres pre incaicos están implícitos en las ofrendas funerarias y son señales seguras del sostenimiento del tráfico de excedentes. Lingoteras, restos de hornos de fundición en Solor (Solor 3 y 4) y Coyo (Coyo Aldea) a raíz de la asociación a bosques, permitió acceder a combustibles, debiéndose trasladar el mineral desde menas cercanas o más lejanas como aquellas de Chuquicamata-Tomic, y las situadas en la cordillera de la costa entre la boca del Loa y Taltal.

El envío de colonias mineras extractivas logró sobrevivir, tal como se advierte en la visita de los Lupacas o en la pervivencia de pastores-mineros en Lípez, demostrándose que el proceso se introdujo al interior de la administración inca y española desde los primeros contactos, como obra de mano y guía en el redescubrimiento de menas ya explotadas (Lozano Machuca 1992). Esta relación histórica entre los oasis de San Pedro y grupos dedicados a la fundición se ha identificado en Beter (siglo XVII), detectándose residuos de hornos y talleres de implementos y orfebrería Hispano-Indígena (Marquet et al. 1998).
Por lo anterior y pensando en las numerosas colecciones metálicas provenientes de cementerios de Atacama (Murphy et al. 1999 Ms), se reconoce un proceso intra-puneño responsable de una producción especializada que desde $1200 \mathrm{AC}$ a 1500 DC tuvo el tiempo suficiente para constituir una tradición en el área, en términos de perfeccionar paleotécnicas minero-metalúrgicas cuyos productos de exportación fueron movidos a través del tráfico caravanero (Núñez 1987). La unidad operativa se desarrolló a través de grupos especializados en la explotación de afloramientos alejados de valles y asentamientos permanentes, dada la localización de los locis mineralizados. Los campamentos pre incaicos ubicados en las minas actuales de Chuquicamata. Abra, Tomic, Cerro Verde, Collahuasi y otros, se relacionan estrechamente con exploraciones post Tiwanaku muy intensas (Núñez 1994 Ms y 1994 Uribe y Carrasco en este volumen). Estas estructuras pircadas asociadas a espacios estériles, pero ubicadas junto a menas expuestas, podrían relacionarse al hallazgo de un minero accidentado in situ como es el llamado "Hombre de Cobre" en Chuquicamata (Bird 1977 y 1979).

El potencial minero de la Subárea Circumpuneña se ha constatado precisamente en las numerosas colecciones del Museo Arqueológico de San Pedro de Atacama, que datan de momentos tempranos y medios (400-1200 DC). El inventario cuenta con 1.331 artefactos separados en 1.109 unidades de cobre y/o bronce, 180 unidades de oro, 35 unidades de plata, y 9 unidades de estaño y plomo (Téllez, com. pers., 1999). Esta alta representatividad no es común en otras colecciones del norte del país, demostrándose una estricta relación con la disponibilidad de recursos en la cuenca del Salar de Atacama (minas de Tupe, Peine, San Bartolo y Chulakao/Coyo), incluyendo por otra parte aquellos recursos situados a lo largo del río Loa, y Cordillera de la Costa. En los momentos tardíos la élite local incrementó las operaciones al exterior hasta su anexión al estado inca, perdiéndose el prestigio iconográfico Tiwanaku y generándose una situación de escasez de bienes metálicos a nivel de la mayoría de la población. 


\section{La atracción minera en torno a la expansión incaica meridional}

La concepción andina de la minería se vincula a los atributos de Pachamama ya que el metal es producto de la tierra, en donde la plata será papa y lo mineral se relacionará con la montaña, porque las vetas se criarán y reproducirán como las plantas (Harris y Bouysse-Cassagne 1988). Así, el cobre nativo será charqui y su extracción será legitimizada por rituales donde se rogará por el aumento de la veta, de tal modo que estos valores andinos compartidos permitieron asimilar en corto tiempo el dominio incaico que controlaría y administraría la riqueza minera de sus provincias.

Puesto que el uso de los metales en la sociedad andina estuvo más orientado al ceremonial que a menesteres domésticos, se le atribuye a los incas la aplicación de una fuerte política tras el control de estos recursos, justificando por esta vía la colonización de amplias regiones de los Andes. Sin los metales no habrían insignias ni boato del poder: menas y mineros debían, por razones absolutistas, constituir fuentes y energías para el estado. De modo que la producción metalúrgica desde antes y con los incas fue una labor compleja y especializada, sometiéndose a un incremento para la consolidación del rol político y simbólico a través de "rescates" desde las provincias mineras de ambos nortes (A.R. González 1983, L.R. González 2000, Raffino 1978 y 1986).

Los incas reconocieron en el sur la existencia no sólo de piezas fundidas notables, sino sus minas y la relación entre minerales y ritualidad. Entre los caravaneros de la circumpuna eran comunes las ofrendas de mineral de cobre molido (turquesa, malaquita), tanto en las "cajas" del río Loa (Berenguer 1994, Sinclaire 1994) como en las "tapadas" o concentraciones de mineral dispuestas en las rutas del Loa, Atacama y Lípez (Núñez et al. 1977, Nielsen 1997-98 Ms). Ofrendas en los pasos obligados y ritualizados como las abras o al pie de bloques con petroglifos indican que las rocas trituradas de cobre de color eran consideradas el alimento de las deidades de pastores y caravaneros (Núñez 1987). De acuerdo a la etnografía local eran también ofrecidas a los cerros para agradecer y fortalecer el apoyo del panteón andino al paso de las caravanas a través de las subáreas Circumpuneña y Altiplano Meridional.

Fue esta riqueza tanto tecnológica como ideológica, la atracción que motivó a los incas a establecer alianzas con las élites locales de ambas vertientes de la cordillera, asegurando para sí las más altas cuotas de excedentes derivados de la ampliación de la escala productiva local. En distritos donde advirtieron riqueza, sea de recursos renovables como mineros, legitimizaron a las autoridades étnicas locales con alianzas políticas y coberturas ideológicas, adueñándose de todos los bienes reproducibles (Murra 1978). Una vez que se establecía la apropiación de los espacios prioritarios (p.e. minas), se devolvían las tierras de uso agropecuario a sus dueños, dejando cierto hectareaje para asegurar los obrajes minero-metalúrgicos. En este sentido, fue la tributación al estado de parte de las jerarquías locales, en términos de entrega de mita, el aporte multipropósito orientado a labores de labranza, crianza de ganado, confección de vestimentas, construcción de edificios y labrado de minas (Murra 1978).

De acuerdo al "orden inca" existían visitas "oficiales" hacia los territorios anexados con cierta periodicidad bajo ceremoniales interculturales específicos (Regalado de Hurtado 1997). El poder político y social era demasiado estricto como para no integrar directamente a aquellos distritos donde minerales y piedras preciosas eran sustancia viva en el imaginario del sur. Para este efecto organizaba la mano de obra y la asimilación de tecnologías especializadas para acumular excedentes a través de redes de distribución basadas en el prestigio político y religioso de los líderes dominantes e incanizados. A su vez, manipuló directamente el manejo de su propia tecnología, trasfiriendo el secreto de la aleación cobre-estaño en donde se desconocía.

Para controlar este prestigioso distrito minero, la administración inca debió intervenir directamente en torno a la organización de los territorios anexados con aquellas instrucciones aplicadas para la vigilancia económica, social, política y militar (Espinoza 1997). Aunque no se requirió de centros urbanos bastaban los asentamientos administrativos y de almacenaje, mantención de caravanas, residencia de burócratas, ideólogos, maestros de talleres y contadores, establecidos en torno al 
Camino del Inca: Peine Viejo, Catarpe y Turi. Desde aquí se controlaron las mitas, su apoyo logístico, acceso a alimentos en las tierras del Inca, recepción de artesanías e implementos útiles para las labores estatales, inventario de bienes, tiestos para la distribución de chicha y agua, donativos para la élite local, organización de festividades con las autoridades subordinadas, atención para los mitayos locales, arreglos arquitectónicos, medidas de reposición de infraestructura, estímulos a los colaboradores, recepción de tierras y menas con mineros para el Inca rey.

En la vertiente oriental de la Puna, a lo largo de la quebrada de Humahuaca y región jujeña, se han reconocido minas de cobre, oro, plata y estaño (Angiorama 1999). Si bien no existe una alta tasa de colecciones metálicas, hay restos de fundiciones preincaicas (Cultura Yavi), como Cerro Colorado 1 (Sansana), orientados a la explotación de oro (Krapovickas 1968). Reocupaciones incaicas en el mismo yacimiento dan cuenta de su notable intervención sobre minas precesoras que datan de 1520 DC (Krapovickas 1958-59 y 1987).

En la puna jujeña se habría desarrollado el tráfico de minerales a lugares con recursos para las labores de fundido. Al igual que en la Puna Occidental las experiencias minero-metalúrgicas son preincaicas, tal como se ha observado en la quebrada de Humahuaca desde los 1000 DC. Aquí se alcanzó una competente producción con énfasis en el traslado de estaño y oro. Precisamente, en los talleres del Pukara de Tilcara y los Amarillos se recepcionaron minerales, dando lugar a una profusa presencia de implementos metálicos de uso local y excedentario (Angiorama 1999, Krapovickas 1958-59, Tarragó y González 1998, Nielsen 1997-98, Núñez 1987).

Hacia estos distritos mineros se introdujo el control directo en ambas vertientes del Collasuyu sureño, atraídos por la experiencia pre existente, capaz de reorientar su producción esta vez hacia el Cuzco (A.R. González 1979). El hecho de que las fraguas de Cajamarca fundieran en sólo medio año seis toneladas de oro y once de plata, cuando Atahualpa era cautivo, indica que el traslado de lingotes desde las provincias mineras fue consistente con la política estatal de expansión a las menas del sur, tal como lo sugirieron las primeras lecturas etnohistóricas de la expansión inca (Hidalgo 1971). Según Raffino (1978 y 1981) que ésta se extendiera al Collasuyu Meridional se debió al interés por controlar las labores mineras, de acuerdo a la recurrente asociación entre instalaciones incaicas y explotaciones aledañas. Paralelamente, se organizaron los territorios anexados como fuente de apoyo logístico para las labores extractivas, donde a lo menos cinco asentamientos incaicos de la puna jujeña (fase Inca 1430-1535) se asocian a actividades mineras (Raffino 1978, Albeck et al. 1999).

La conquista inca en el norte chileno, se ha interpretado como un efecto indirecto desde el altiplano, dado a que habrían ocupado primero las tierras altas, en donde preexistían interrelaciones a nivel de colonias con las poblaciones locales (Llagostera 1976). Esto significaría que la penetración inca hacia Chile central ocurrió por un espacio ya incanizado. Si bien este carácter de la conexión Altiplano-Valles Occidentales y circumpuna sigue siendo válida, hasta ahora se dispone de escasa información para entender qué recursos fueron explotados para y por el Inca a través de intervenciones administrativas y políticas directas a los largo del territorio circumpuneño (Loa-Salar de Atacama).

El análisis cronológico se ha utilizado para sustentar la tesis de un dominio indirecto, dada la carencia de tiestos imperiales cuzqueños, afirmándose la idea de una pertenencia al interior del Collasuyu, y desde esta provincia incaica transandina se habrían contactado con el Cuzco (Llagostera 1976, Raffino et al. 1983). Sin embargo, se ha constatado la imposición directa de formatos artesanales y otros impactos a través de los cambios funcionales en los contextos depositacionales (Uribe y Carrasco en este volumen). Debe sumarse el estilo inca del arte rupestre (llamas rectilíneas) y la disposición de caravanas estilizadas en rocas-huacas aisladas, tanto en Atacama como en el Loa, sin olvidar los registros etnolingüisticos derivados de la religiosidad (Uribe et al. 1999). Se incluye el manejo político y cívico de los funcionarios incas frente a los señoríos locales, en términos de la disposición de nuevos formatos arquitectónicos (Gallardo et al. 1995) y control directo del incremento de la actividad minero-metalúrgico a través de la recepción del tri- 
buto en energía humana para sostener las mitas de labor especializada local. Tal política de estado se apoyó en términos de alimentos, transporte, bodegaje y gentes disponibles, a través de alianzas con la élite local. Para administrar las minas explotadas como el Abra y Cerro Verde, el estado cuzqueño debió plantear un dominio político directo a lo largo del río Loa Superior y Medio, tal como se observa desde Caspana, en donde el Inca: "Se instala, marca, recorre y produce..., involucrando en distintos grados a toda la población conquistada en su nuevo orden" (Uribe et al. 1999). De acuerdo a los cronistas la labor minero-metalúrgica inca involucraba a especialistas de prestigio así reconocidos por los observadores europeos. Las instalaciones de talleres y colonias mineras fue una preocupación del estado (Garcilaso 1968, Acosta 1962), paralelo al traslado de especialistas, de una región a otra (Cieza 1947 [1553]).

Una prueba de que existía una relación directa entre funcionarios incas y autoridades locales se ha reconocido en el hallazgo de una placa metálica sobre el pecho de un personaje hallado en Sacsayhuaman, con un icono originado entre la élite del sur. Se trata del tema de la placa de Catarpe, expandida a la costa de Taltal (González A.R. 1983, Lynch 1978, Lynch y Núñez 1994, Núñez 1987), similar a aquella de Rinconada de Jujuy y otras "caritas santamarianas". Con ésto, no cabe duda que a pesar de la ausencia de cerámica cuzqueña, este testimonio guarda relación con la radicación temporal o estable de funcionarios incas o incanizados involucrados con la organización de los tributos en las provincias anexadas.

En torno a estas conexiones directas, la carencia de datos sobre la real naturaleza de la relación incarecursos locales ha motivado una sobrevaloración del llamado Camino del Inca, como si su mantención y el flujo de tributos fuera el único rol de las poblaciones locales. De hecho, el camino entre el Loa Superior - San Pedro - Copiapó - costa de Taltal, fue trazado antes, de acuerdo a las evidencia cerámica, debido a la interconexión de los asentamientos locales, aunque su vialidad fue perfeccionada y extendida con la penetración inca (Niemeyer y Rivera 1983). La construcción de asentamientos incas en el Loa Superior y cuenca de Atacama, efectivamente se debería tanto al con- trol vial como a la explotación minera de las tierras altas en torno al Camino del Inca (Cornejo 1995). No obstante, deberían ampliarse estas locaciones, ya que las evidencias incas en Mina El Abra y el hallazgo de un aríbalo Rojo Violáceo en la pampa cercana a Sierra Gorda, dan cuenta de exploraciones y labores mineras retiradas del ámbito del Camino del Inca, constituyendo señales escasas, pero seguras, de explotaciones tan alejadas como la mina de plata de Huantajaya ubicada en el lejano barranco costero de Iquique (Núñez 1978).

Por lo anterior, la propuesta de Uribe y Carrasco (en este volumen: 64) en el sentido que el "inca enfatizará la producción minera sobre la agrícola" es correcta al admitirșe que además de Cerro Verde, y desde el Loa Superior y Medio, se sumó la explotación de otros distritos mineros que ahora se conocen como Chuquicamata, Abra y Tomic, con similares componentes culturales, bajo el control directo de la administración incaica, inserta en el aparato de los kurakas locales. Los personajes enterrados en el Cementerio de los Abuelos, precisamente asimilaron el pensamiento inca en tanto ritualizaron los implementos más emblemáticos incluyendo aquellos de la producción minera, objetos metálicos, minerales y martillos (Ayala 1999, Ayala et al. en este volumen, Uribe y Carrasco en este volumen).

Recientemente se ha comprobado que la cerámica inca del Loa Superior se identifica por sus formatos, aunque fue confeccionada por población local, registrándose algunas de sus formas, como las ollas con pedestal comunes en el Altiplano Meridional. La presencia de cerámica Saxamar en el Loa, por otro lado, establece relaciones con el Altiplano Central y Meridional, integrando además conexiones con los centros incaicos del N.O. argentino identificados a través del estilo Yavi-La Paya Negro s/Rojo (Uribe y Carrasco en este volumen). No obstante, no se aplicaron aquí las herramientas incas dado a que preexistían respuestas laborales bien experimentadas. En este sentido, los medios de producción no se innovaron, ya que no se ven diferencias entre implementos líticos (martillos y palas), en la totalidad de los sitios documentados, tanto en las minas y campamentos asociados, como los que hemos identificado fuera del río Loa o aquellos de Caspana (Uribe y 


\section{Carrasco en este volumen).}

Por otra parte, las vasijas de la mayoría de los sitios mineros incas se corresponden con logros tecnológicos del Período de Desarrollo Regional Avanzado: Turi alisados, revestidos y Dupont, Aiquina y S.P. Rojo Violáceo, es decir, aquellos que integran el componente Loa-San Pedro (Uribe 1997 y 1999). Esto significa que los bienes de producción y de uso eran suficientemente idóneos durante la aplicación de la política de expansión minera incaica, manteniéndose las tecnologías previas, en un territorio integrado por sus valores más mineros que agrarios, a través de una intervención más directa de lo que se había supuesto (Uribe y Carrasco en este volumen).

La relación entre asentamientos incas y el camino homónimo planteado para el Loa Superior, se advierte coherente y obvia desde una visión de apoyo al flujo de tributos (Cornejo 1995, Uribe 1999, Castro 1992 y otros). Sin embargo, se requiere de mayor información para esclarecer el rol de las actividades minero-metalúrgicas asociadas entre asentamientos y distritos mineralizados específicos. La presencia de mineral de cobre en aldeas preincaicas entre Tulán y Tilocalar y de objetos metálicos de cobre y oro desde etapas formativas, presuponen menas locales, como las existentes en Peine, aunque no hay investigaciones que permitan correlacionarlas con el gran asentamiento inca de Peine Viejo (Núñez 1995). En el caso del centro administrativo Catarpe se ha advertido la presencia de oro, artefactos de cobre, fragmentos de turquesa, de planchas y crisoles, cobre deformado y escoria en estrecha relación con la explotación de cobre en el ámbito de S.P. de Atacama (minas de San Bartolo), incluyendo posibles labores de fundición local (Lynch 1978, Lynch y Núñez 1994).

En el Loa Superior, Cerro Verde presenta instalaciones típicamente cuzqueñas, asociadas a ocupaciones con cerámica inca local y del N.O. argentino, incluyendo componentes típicos del patrón Loa-San Pedro, cuando se habrían incrementado las actividades entre las aldeas y labores mineras del Loa Superior, como es el caso de Caspana y las mitas para Cerro Verde (Uribe y Carrasco en este volumen).
La explotación en Cerro Verde se tipifica por las concentraciones de mineral de cobre triturado y malaquitas distribuidas en Talikuna, Cementerio de los Abuelos y Turi. La presencia de cantos desbastados da cuenta de labores de martillado y/o machacado, asociados a palas de uso minero, ya observado en el registro del "Hombre de Cobre" (Uribe y Carrasco, en este volumen, Ayala 1999, Bird 1979, Núñez 1998 Ms a). Por otro lado, recientemente se ha informado del tráfico de minerales de cobre de color a lo largo del Loa Superior, constituyendo áreas de trabajo especializado, incorporado seguramente a la administración inca (Rees y De Souza 2000 Ms).

Otro caso que relaciona la expansión inca a la explotación minera se identificó en el nacimiento del Loa (volcán Miño) en el asentamiento KonaKona-1, con eventuales labores de extracción de plata, dando lugar a instalaciones pervivientes hasta el siglo pasado. Los restos cerámicos indican una primera ocupación durante el Período Intermedio Tardío, seguida de ocupaciones altiplánicas Kollau y posteriores o históricas (Castro 1992). Allí se identificaron asentamientos con cerámica Inca, Inca-Paya y Saxamar, junto a tiestos Rojo Violáceo y otros del componente LoaSan Pedro, provenientes del traslado de mano de obra orientada básicamente a la labor minera dado a que el distrito es altamente mineralizado y despoblado a su vez (Castro 1992).

El rol del Pukara de Turi (sección inca) no debió estar exento a la acumulación y distribución de excedentes mineros del Loa Superior (Gallardo $e t$ al. 1995), tal como sucedió más al norte con Collahuasi. El registro de este caso se inserta en una intensa ocupación inca entre el Loa Superior y el altiplano tarapaqueño, reiterando una estrecha relación entre el control inca y los recursos mineros locales adosados precisamente al Camino del Inca a través de una instalación del orden de los $3.377 \mathrm{~m}^{2}$ (Lynch y Núñez 1994).

El sitio altiplánico Collahuasi se localiza en un distrito minero prestigioso en donde se prospectaron 65 sitios, entre preincaicos $(18 \%)$, incaicos $(3 \%)$, coloniales $(4,5 \%)$ y republicanos tempranos (56,9\%) (Núñez $1997 \mathrm{Ms})$. Entre las evidencias incas el sitio Collahuasi-37 es el de mayor densidad prehispánica, con nueve locis ar- 
quitectónicos. En superficie se advierten escasos restos de cerámica cuzqueña y más frecuentes fragmentos provinciales procedentes del altiplano centro-meridional aledaño (p.e. Inca Pacajes o Saxamar) y varios tipos domésticos monocromos más dominantes. (Romero y Briones en este volumen).

La arquitectura presenta el clásico formato perimetral compuesto, nichos trapezoidales intramuro, plantas de recintos trapezoidales, patios con silos agregados, plaza o patio central, conjuntos de collcas o bodegas aglutinadas en "media luna" y circulares aisladas, entre otros. Corresponde a un programa, donde parece que habitaban funcionarios, servidores de tambos y de minas, provenientes de poblaciones estables, relativamente cercanas al área, para acumular y movilizar tributos. La presencia de minerales, pisos con ceniza y la toponimia quechua en las cumbres aledañas, hacen pensar que los incas organizaron la explotación de los filones superficiales de Collahuasi acorde con su expansión al sur. En tanto se emplaza junto a la vía inca, siguiendo la tendencia, con estructuras de grandes corrales y abundantes bodegas, en partes relacionadas con el recurso minero de Collahuasi, perfilándose como el locus metalífero intermedio o el número once de los diez descritos por Raffino (1981), básicamente entre las evidencias del valle de Camarones y el Loa Superior.

La presencia de cerámica tardía de las tierras altas y algunas de los oasis bajos piqueños, podría sugerir traslados de gentes y tributación desde áreas con ocupaciones agropecuarias y agrarias aledañas, desde las pendientes occidentales y orientales de la altiplanicie de Collahuasi. Aquí se habría organizado un intenso manejo de la mita minera desde poblaciones anexadas, paralelo a la recepción de bienes de los Valles Occidentales y Altiplano Meridional aledaños, en un distrito despoblado que no involucró manejos políticos locales. La ubicación de Collahuasi en el pleno distrito cuprífero, sugiere que las labores fueron potenciadas durante el régimen inca. Dada la carencia de ocupaciones permanentes anteriores, a partir de esta explotación se valoró su desarrollo minero-metalúrgico, esta vez en una amplia escala de menas cobre-oro. El registro de múltiples sitios de extracción y fundido de cobre, explotados du- rante los s. XVII, XVIII y XIX (hasta el comienzo del XX), indica que este distrito fue bien evaluado e incrementado por los mineros locales bajo la administración inca.

\section{Las evidencias mineras del distrito El Abra}

Prospecciones preliminares. El registro de sitios se concentró en serranías estériles a unos 10-15 km al NO del río Loa (Estación Conchi), mayormente en las quebradas llamada de la Aguada, en razón de la principal vertiente ubicada en su cabecera y de la quebrada las Ruinas donde se localizaron varios sitios vinculados con minas prehispánicas, incluyendo el sector colonial de Conchi Viejo, entre cotas altas del orden de los 3000 a 3500 m.snm (Figura 1). Precisamente en la primera quebrada se ubicó el sitio Ab-33 de data inicialmente preincaica y en la segunda a un conjunto de sitios que se relacionan con la principal mina inca-local el Abra (Ab 35, 36, 37 y 38). Se prospectaron tantos las áreas mineralizadas como las quebradas referidas y los alrededores cercanos al río Loa en una primera fase, considerándose sólo los sitios de mayor visibilidad (una segunda fase de exploración no fue realizada). El patrón de designación de sitios se recuperó del toponímico local Abra o Portezuelo que da paso al Loa desde la serranía homónima (Núñez 1998 $\mathrm{Ms})$.

La prospección sumó un total de 47 sitios de los cuales los recintos de actividades mineras pirquineras correspondientes a los siglos XIX y XX son los más frecuentes ( 17 sitios). Confirman una alta recurrencia los asentamientos y campamentos prehispánicos tardíos mineros en torno a las quebradas de la Aguada y de las Ruinas (15 sitios). Esta clase de sitios históricos y prehispánicos indican una orientación prioritaria del uso de los recursos mineros locales. Las escasas evidencias de sitios arcaicos se debe a que estos se apegan a los recursos del borde del río Loa, alejándose de las áreas mineralizadas ( 3 sitios), al igual que los más escașos sitios con petroglifos tardíos (1 sitio). No obstante, el registro de cerámica formativa avanzada (p.e. negra pulida clásica) al interior de un recinto atípico $(\mathrm{C} 2)$ del sitio $\mathrm{Ab}-33$, sugiere que en torno a la Aguada de la Quebrada se nucleó un asentamiento que utilizó el espacio con mayor recurso de agua y vegetación para acceder desde aquí 
a los afloramientos cupríferos a través de una ocupación pionera previa a la implantación inca-local de mayor escala.

El registro de 4 sitios correlacionados con obras de fundición de cobre, válidos para el siglo XVIII, en Conchi Viejo, estaría vinculado con minas más apegadas al río Loa (gran mina de Conchi) y no con las quebradas del área de la mina prehispánica Abra, dada la ausencia de rasgos coloniales fuera de Conchi Viejo. El modelo de explotación del área Conchi Viejo lo fue la extracción y fundición minera hasta las postrimerías del régimen colonial, disponiéndose los escasos recursos naturales locales hacia estos objetivos minero-metalúrgicos (Figura 2).

\section{Sitios componentes del sistema extractivo prehispánico}

Del registro de prospección se han seleccionado aquellos sitios relacionados con la explotación de las menas en la quebrada de las Ruinas (Figura 2 y 3):

\begin{abstract}
Abra-35 (21 ${ }^{\circ}-55$ '-16.1''/68 ${ }^{\circ}-50$ '-57.0'): Corresponde a un refugio pircado asociado a una veta socavada y una cancha en donde se registró cerámica roja violácea, café alisada tardía y restos de martillos. A su lado se practicó un pique moderno en la misma veta que aflora en la alta pendiente de la quebrada Aguada. La presencia de mineral de cobre triturado y restos de martillo sugieren una función de selección de mineral de color.
\end{abstract}

\begin{abstract}
Abra-36 (21 $\left.{ }^{\circ}-55^{\prime}-32.1^{\prime \prime} / 68^{\circ}-50^{\prime}-38.2^{\prime \prime}\right)$ : Es un asentamiento complejo separado por dos conjuntos localizados en el curso inferior de la quebrada de las Ruinas. Ambos sectores serían sincrónicos a juzgar por la similitud arquitectónica y cerámica, ocupando el sector más amplio de la quebrada cercano a recursos de agua potable a unos $200 \mathrm{~m}$ quebrada arriba.
\end{abstract}

El conjunto 1 o menor se compone de 3 recintos con divisiones modificadas y un espacio exterior pircado y abierto con densos depósitos de fogones, desperdicios de alimentos y cerámica. Está separado del conjunto 2 a través del cauce seco. Presenta una separación muy neta entre el sector residencial y el corral para recuas de llamas. En efecto, está muy clara la diferencia de las estructuras pircadas sub-cuadrangulares, las que debieron estar debidamente techadas, tal como se advierte en un sector. Se distingue, además, una puerta trapezoidal inca y divisiones interiores eventualmente reocupadas.

El conjunto 2 es el de mayor densidad localizado frente al anterior, utilizando también grandes bloques de granito e ignimbrita, extraidos desde las canteras que afloran en el borde de la misma quebrada. Se compone de varias unidades arquitectónicas con distintas funcionalidades no bien definidas por la carencia de excavaciones. El acceso desde aguas arriba de la quebrada ocurría entre dos recintos circulares, separados por unos $8 \mathrm{~m}$ del gran complejo arquitectónico, conformado por un típico perímetro compuesto, con sus muros laterales abatidos y restos de posibles poyos interiores.

Los tres perímetros compuestos del sitio se tipifican por la construcción de muros con rocas tendidas horizontalmente en sus bases, observándose bloques más irregulares en los cabezales de los muros a raíz de la reconstitución posterior de ciertos tramos de los recintos, destacándose un patrón de bodegas esquinadas en sectores no intervenidos. El perímetro del sector norte incluye además grandes canchas interiores y un sector con dos recintos residenciales asociados a cuatro bodegas sub-cuadrangulares de construcción continuas, todo dispuesto en un largo terraplén artificial sostenido con un muro inclinado de contención que corre paralelo al cauce seco.

El segundo perímetro se dispone perpendicularmente al interior, separado por un pasadizo y un núcleo eriazo, como una cancha abierta. Dentro de este perímetro se han reconocido cuatro estructuras entre residencias y bodegas. Aquí se destaca una bodega muy jerárquica de planta rectangular con una división interior, configurando una cuidadoso tratamiento de albañilería inca. Esta estructura presenta muros muy rectilíneos cubiertos de bloques abatidos, preparados con lajas horizontales de caras planas al exterior ajustadas con cuñas. Precisamente en el muro oeste se identificó un nicho trapezoidal del más puro formato inca (Figura 4). Hacia el sur, al exterior del perímetro 
analizado se identificaron nueve bodegas aisladas y agrupadas al muro periférico destacándose una cancha o emplantillado de bloques ocupado para la eliminación de estériles o impurezas con técnicas de martillado. Entre ambos perímetros compuestos se sitúa un sector sin estructuras o patio eriazo que a juzgar por la abundancia de martillos y restos de mineral se trataría de un espacio dedicado a la reducción de estériles de los minerales de cobre de color (Figura 5).

El análisis de la superficie del sitio Abra-36 demuestra la presencia de fogones y desechos alimentarios, con abundante registro de huesos de camélidos, roedores, cerámica y restos orgánicos que posibilitan futuras excavaciones. Sin embargo, también hay restos muy minoritarios de materiales modernos: latas, vidrios e implementos de fierro vinculados con reocupaciones de pirquineros del presente siglo.

Son comunes los registros de martillos de rocas cortezadas, tanto en la superficie de los recintos como en las canchas, usados para desprender la roca estéril o "encajadora". Generalmente presentan un extremo percutido o descortezado, con cuello o acinturamiento pulido por la aplicación y erosión del enmangamiento. Entre los depósitos intramuros son comunes los restos de mineral de color, restos de camélidos y martillos con escotadura central. Entre la cerámica se destacan tiestos café alisados, estriados y pulidos, rojo violáceo grueso-fino y rojos pulidos y bruñidos. El alto uso de cerámica, indicaría que las labores eran permanentes, asociadas a recintos habitacionales y de labor, con funciones relacionadas a los campamentos aledaños $\mathrm{Ab}-37$ y 38, ubicados unos $500 \mathrm{~m}$ aguas arriba, dependientes también de las labores de extracción y selección de mineral, emplazados en un espacio más estrecho de la quebrada, pero más cercano al afloramiento minero (Figura 3).

Abra-37 (21 ${ }^{\circ}-55^{\prime}-0.2^{\prime \prime} / 68^{\circ}-50$ '-56.5'): Se trata de un pequeño campamento compuesto de dos conjuntos (Figuras 3 y 6). El más complejo se constituye por dos recintos al parecer residenciales, enfrentados en la pendiente opuesta por la mina socavada y sus correspondientes muros de contención. Se separa por unos $24 \mathrm{~m}$ del otro campamento Abra-38. La primera impresión lateral es que configura un emplantillado confuso de bloques, sin embargo, desde la distancia se aprecian mejor los dos conjuntos, cubiertos con material percutido, constituyendo manchas claras correspondiente al material estéril desprendido. El otro corresponde a una cancha aislada y pircada con abundante desecho de percusión de estéril en su interior y múltiples restos de martillos, preparada con un terraplén artificial suficientemente nivelado.

Uno de los detalles estructurales diagnósticos del sitio es la localización de varios recintos pircados circulares, incluyendo sectores más abiertos, en donde se percutió el mineral para separarlo del estéril. Los martillos grandes presentan escotaduras en donde originalmente se colocaba el enmangado atado con cueros rígidos, con desgaste en un extremo, mientras que otros más pequenos presentan filos bifaciales, con mayor aplicación de percusión, constituyendo verdaderas hachas de formas crudas seguramente usadas para trabajos más afinados. Se registraron tiestos café alisados, estriados y pulidos, incluyendo rojos violáceos, rojos pulidos bruñidos y negro sobre rojo pulido.

Abra-38 (21 ${ }^{\circ} \mathbf{- 5 5}$ '-02.6"/68 $\mathbf{- 5 6}$ '-56.6'): A unos
24 m del conjunto anterior se identificó el campa-
mento Abra-38, compuesto por un perímetro inca,
eventualmente con una división interior y dos bo-
degas agregadas al muro oriental. En el recinto
del noreste se ubicó una estructura exótica con su
acceso no modificado y un sector interior muy es-
trecho de función no conocida, limítrofe a una
cancha abierta, cubierta de un emplantillado o piso
de bloques planos. Aquí se encuentran varios mar-
tillos y percutores semiesféricos vinculados con
la separación del material estéril.

Este sitio fue intervenido por una máquina pesada, alterándose el piso en el sector central, exponiéndose un depósito con fragmentos de cerámica roja pulida y bruñida inca, asociada a restos óseos de llamas, incluyendo fogones con gruesos carbones de leña. Los muros del sector nuclear se advierten muy removidos por la acción mecánica, pero se observa en las bases las típicas lajas horizontales, destacándose una bodega con nicho semitrapezoidal bajo un derrumbe. En la superficie se ubican sectores de molienda reconocidos 
por la presencia de yunques planos asociados a martillos pesados de extremo semiesférico, tal vez usados como maráy, encontrados junto a los típicos martillos comunes en el área. También son frecuentes los restos de cerámica y cobre dentro de las canchas y en los alrededores de los recintos, como en el sitio anterior, vinculados a martillos de granito cortezado percutidos esta vez en ambos extremos.

\section{$\operatorname{Abra}-39\left(21^{\circ}-55^{\prime}-0.26^{\prime \prime} / 68^{\circ}-56^{\prime}-56.6^{\prime \prime}\right)$}

Abra-39/A: Frente a los asentamientos antes descritos se alza la pendiente donde se localiza el afloramiento cuprífero bajo los pircados de contención de avalanchas. En la cúspide se identificaron tres estructuras separadas: una semi circular de posible data prehispánica y las otras dos en forma de "U" con restos modernos de alambre, madera y un yunque lítico para la molienda.

Abra-39: Se trata de tres grandes líneas paralelas de muros de contención que guardan relación con defensas aluvionales de flujos que solían derramarse sobre las labores de extracción. La técnica del pircado es homóloga a los muros de los asentamientos prehispánicos y en sus entornos se aprecian grandes acumulaciones de estériles extraídos en tiempos antiguos y recientes y en otros el efecto erosivo los ha cortado de manera segmentado.

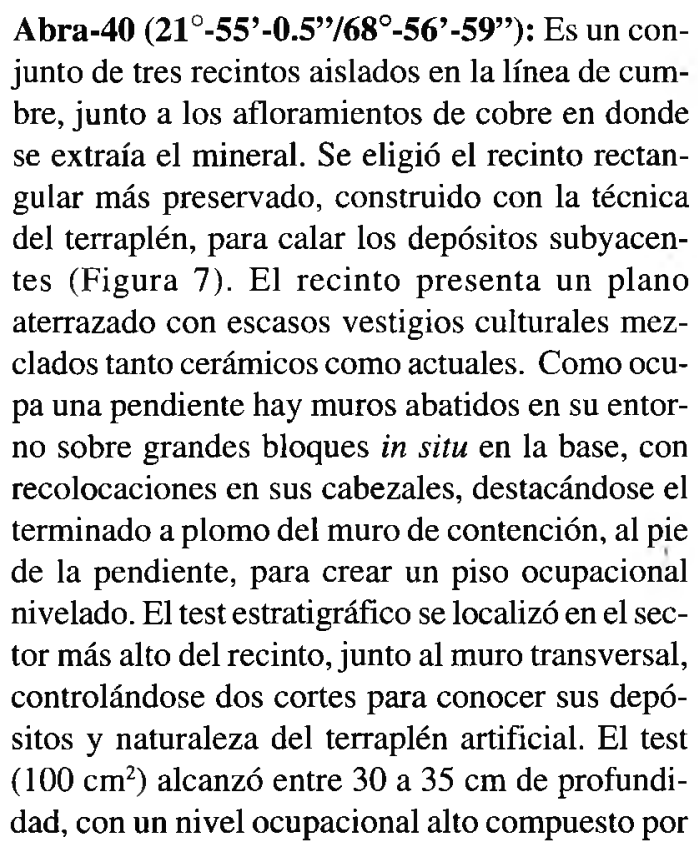

corpúsculos de carbón asociado a fragmentos de cerámica (Figura 7). Asociado al nivel de fogones se registraron restos de turquesa, carbón, ganga, cerámica café pulida y rojo pulido interior. Una ocupación subyacente presentó fragmentos de cerámica roja pulida de tradición inca-local, similares a los campamentos mineros ubicados en el fondo de la quebrada (Ab-36, 37 y 38). Se trataría de una cancha con labores de cocina y depósito de turquesa, extraída de la mina cercana (Ab-22). Desde aquí se acumularía el mineral para ser transportado hacia los campamentos inferiores, a través del sendero despejado, que sale de este recinto hacia el fondo de la quebrada, donde se sitúan los campamentos.

Abra-22: Al revisar la línea de cumbre y la pendiente sobre la mina prehispánica entre los sitios Ab-38 y 37, se identificó el área de afloramiento de turquesa y de extracción con martillos cuyos fragmentos desechados por fractura fueron registrados con alta frecuencia. Se obtuvo una muestra con distintas clases de variación morfológica: fragmentos percutidos en la parte distal y proximal, de cuerpos más completos con fracturas dístales menores y cuerpos poco astillados que responden a martillos completos en donde se aprecian las típicas escotaduras del enmangamiento.

Abra-43 (21'-55'-17'/68'-50'-35'): Corresponde a un recinto subrectangular aislado, con un apéndice, ubicado al fondo de la quebrada de las Ruinas ( $1 \mathrm{~km}$ agua arriba de la mina prehispánica) situado muy cerca del estero seco con escasa posibilidad espacial para ocupaciones intensivas. El interior del recinto está preparado con un terraplén artificial apoyado por el muro de contención asociado a martillos. Se registró al interior y en los bordes del recinto fragmentos de cerámica café alisada regular y gruesa y roja violácea pulida exterior, además de martillos de extracción. Se ubicó el test $\left(100 \mathrm{~cm}^{2}\right)$ en el sur del recinto, junto a los martillos y fragmentos de cerámica ubicados en la superficie. En el depósito de 14 a $20 \mathrm{~cm}$ de espesor, sobre una base estéril compacta, se ubicó un lente de fogón asociado a un martillo de extracción de mineral in situ. Se trata de un recinto vinculado con la extracción y reducción de los filones mineralizados socavados en la pendiente opuesta, similiando a los sitios Ab-36, 37 y 38 a través de la tipología de martillos y cerámica. 
Abra-44: Es un conjunto de varios recintos ubicados en el fondo de una quebrada seca que desemboca en la quebrada de las Ruinas, aguas abajo del sitio principal (Ab-36), asociado a una vega.

Recinto-a: Presenta bloques graníticos apegados al afloramiento rocoso del borde de la quebrada, con su acceso alterado por un bloque caído. La técnica del muro es de doble hilada sin argamasa con relleno en el interior de data reciente. El recinto se ubica unos $250 \mathrm{~m}$ aguas abajo del anterior con muros abatidos y apegados a un gran bloque preexistente al recinto. Se confirmó la ausencia de rasgos prehispánicos de modo que de acuerdo al material superficial, cercano al sitio, este se correlaciona con el anterior (s. XX). El recinto b/ 1: da cuenta de un terraplén pircado sin evidencias de depósitos ni material cultural superficial, correlacionado con los anteriores de acuerdo al patrón constructivo (cancha reciente?). El recinto-c es elíptico construido con un típico patrón diferenciado, con lajas empotradas verticalmente, al cual se le agregó una estructura pircada subcircular de data más tardía, con muros más anchos por acumulamiento de bloques. En la superficie y debido a una alteración vial se lograron registrar restos prehispánicos: coprolitos, huesos de camélidos, carbón, fragmentos de cobre fundido, lasca de calcedonia, cerámica gris alisada regular y fina, roja alisada, roja pulida y café alisada. Se localizó el test en el interior del recinto, delimitado con un muro de una fila, erosionado, con bordes algo difusos. Bajo los 3-5 cm de la superficie se ubicó el techo de un fogón extendido con corpúsculos de carbón asociado a huesos y coprolitos de camélido adulto, mineral de cobre, carbón, cerámica café alisada regular y fina.

El lente carbonoso superior se separa por un sello estéril café claro del depósito inferior donde se situaron restos de turquesa, huesos de camélidos adultos, carbón, lámina lítica percutida, cerámica café alisada, gris alisada y roja alisada. Se trata de dos niveles de ocupación con actividades de fogones separados por un intervalo de abandono, asociado a abundantes restos de huesos de camélidos adultos consumidos in situ. La presencia de mineral de cobre y restos de metal sugiere una ocupación minero-extractiva con presencia de cerámica prehispánica. El recinto-d presenta un emplantillado de piedra muy abatido que no deja ver el interior del recinto subrectangular. Este presenta una prolongación pircada más baja que da refugio a actividades domésticas donde se aplicó un test de prueba $\left(100 \mathrm{~cm}^{2}\right)$. Presenta un depósito con lentes de fogones de 10-12 cm de espesor promedio sobre la base estéril, en cuya discordancia se situaron dos bloques planos como yunques. Se suma a este estrato único la presencia de escasos fragmentos de cerámica no diagnóstica, de modo que no es seguro afiliar este sitio con el anterior (Figura 8).

Abra-24 (21054'-48,4'/68 .49'-16.1'): Se trata de un recinto aislado constituido por una pirca adosada a la roca natural. Se registran materiales mezclados tanto indígenas como modernos de pirquineros. Entre los primeros se destacan restos de tiestos con el desgrasante.del patrón Río Grande (s. XIX y XX) y otros recientes con mezcla de lascas de basalto, artefacto triangular unifacial (sílice) y fragmento de raedera unifacial (toba). En el interior del refugio se ubicó un afloramiento de fogones. Bajo un leve depósito estéril de no más de $5 \mathrm{~cm}$ de espesor se ubicó un lente de fogón (Figura 9). El estrato I está representado por componentes mezclados sobre el fogón: turquesa, huesos de camélidos, artefactos de sílice y cerámica café alisada. El estrato II se constituye por rasgos intra fogón y subyacente hasta la base estéril: ganga, turquesa, huesos de camélidos, carbón y cerámica del patrón Río Grande.

Se trata de un sitio con componentes culturales mezclados, concentrados en fogones superpuestos y de acuerdo con la cerámica se trataría de una ocupación prehispánica asociada a labores extractivas que se reactivaron hasta el inicio del siglo $\mathrm{XX}$.

En suma, se han identificado diez sitios de filiación inca-local en el entorno de la mina Abra, no contándose hasta ahora con ocupaciones mineras anteriores o posteriores en torno al yacimiento (Tabla 1).

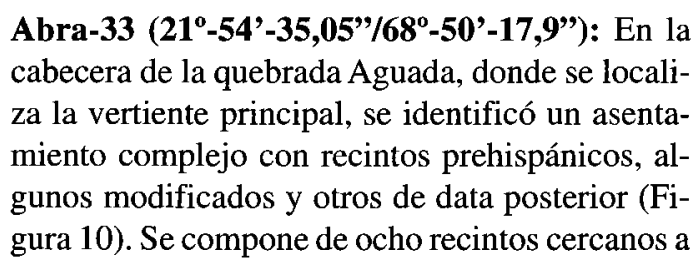


Tabla 1. Sitios relacionados con la explotación minera prehispánica

de la quebrada de las Ruinas (Abra)

\begin{tabular}{|c|c|c|c|c|}
\hline Código & Tipo de Sitio & Labor & Densidad aprox. & Epoca aprox. \\
\hline Abra-35 & $\begin{array}{l}\text { Campamento de grupos } \\
\text { de tareas de extracción } \\
\text { inicial. }\end{array}$ & $\begin{array}{l}\text { Pique inicial de explo- } \\
\text { tación con martillo y } \\
\text { minerales sobre can- } \\
\text { cha. }\end{array}$ & $25 \mathrm{~m}^{2}$ & $\begin{array}{l}\text { Inca y Desarrollo Local } \\
\text { (evidencia cerámica). }\end{array}$ \\
\hline Abra-36 & $\begin{array}{l}\text { Poblado con residen- } \\
\text { cias, bodegaje, can- } \\
\text { chas, corrales, áreas de } \\
\text { martillado y fogones } \\
\text { (perímetro inca). }\end{array}$ & $\begin{array}{l}\text { Alta concentración de } \\
\text { residencias y martillado } \\
\text { de minerales (extrac- } \\
\text { ción de estéril y mo- } \\
\text { lienda). }\end{array}$ & $1.350 \mathrm{~m}^{2}$ & $\begin{array}{l}\text { Inca y Desarrollo Local } \\
\text { (evidencia lítica, cerá- } \\
\text { mica tardía y arquitec- } \\
\text { tura perimetral con ni- } \\
\text { cho trapezoidal). }\end{array}$ \\
\hline Abra-37 & $\begin{array}{l}\text { Campamento restrin- } \\
\text { gido con residencias, } \\
\text { canchas y áreas de mar- } \\
\text { tillado. }\end{array}$ & $\begin{array}{l}\text { Martillado sobre mine- } \\
\text { ral en cancha. }\end{array}$ & $225 \mathrm{~m}^{2}$ & $\begin{array}{l}\text { Inca y Desarrollo Local } \\
\text { (evidencia cerámica y } \\
\text { lítica. }\end{array}$ \\
\hline Abra-38 & $\begin{array}{l}\text { Campamento restrin- } \\
\text { gido con residencias, } \\
\text { canchas y áreas de mar- } \\
\text { tillado (perímetro Inca). }\end{array}$ & $\begin{array}{l}\text { Martillado y molienda } \\
\text { sobre mineral dispues- } \\
\text { to en canchas. }\end{array}$ & $400 \mathrm{~m}^{2}$ & $\begin{array}{l}\text { Inca y Desarrollo Local } \\
\text { (evidencia cerámica, } \\
\text { lítica y arquitectura). }\end{array}$ \\
\hline Abra-39A y 39 & $\begin{array}{l}\text { Area de extracción y } \\
\text { muros de contención. }\end{array}$ & $\begin{array}{l}\text { Extracción y martilla- } \\
\text { do. }\end{array}$ & $1.500 \mathrm{~m}^{2}$ & $\begin{array}{l}\text { Inca y Desarrollo Lo- } \\
\text { cal. Hay socavados de } \\
\text { minas más recientes. }\end{array}$ \\
\hline Abra- 40 & $\begin{array}{l}\text { Cancha de altura con } \\
\text { camino Inca que des- } \\
\text { ciende a Abra- } 36 \text {. }\end{array}$ & $\begin{array}{l}\text { Concentración de mi- } \\
\text { nerales. }\end{array}$ & $15 \mathrm{~m}^{2}$ & $\begin{array}{l}\text { Inca y Desarrollo Local } \\
\text { (evidencia cerámica). }\end{array}$ \\
\hline Abra-22 & $\begin{array}{l}\text { Area de exposición de } \\
\text { vetas asociadas a espa- } \\
\text { cios abiertos de percu- } \\
\text { sión. }\end{array}$ & $\begin{array}{l}\text { Extracción y martillado } \\
\text { (varios sectores). }\end{array}$ & ca. $800 \mathrm{~m}^{2}$ & $\begin{array}{l}\text { Inca y Desarrollo Local } \\
\text { (evidencia lítica y cerá- } \\
\text { mica). }\end{array}$ \\
\hline Abra-43 & $\begin{array}{l}\text { Campamento restrin- } \\
\text { gido. }\end{array}$ & $\begin{array}{l}\text { Extracción y martilla- } \\
\text { do. }\end{array}$ & $15 \mathrm{~m}^{2}$ & $\begin{array}{l}\text { Inca y Desarrollo Local } \\
\text { (evidencia lítica y cerá- } \\
\text { mica). }\end{array}$ \\
\hline Abra-44 & $\begin{array}{l}\text { Campamento multi- } \\
\text { componente Recinto C. }\end{array}$ & $\begin{array}{l}\text { Refugio-residencia con } \\
\text { restos alimentarios. }\end{array}$ & $10 \mathrm{~m}^{2}$ & $\begin{array}{l}\text { Inca y Desarrollo Local } \\
\text { (evidencia cerámica). } \\
\text { El resto de las cuatro } \\
\text { estructuras son moder- } \\
\text { nos (s. XIX y XX). }\end{array}$ \\
\hline Abra-24 & $\begin{array}{l}\text { Campamento multi- } \\
\text { componente. }\end{array}$ & $\begin{array}{l}\text { Refugio-residencia con } \\
\text { restos alimentarios y } \\
\text { mineros. }\end{array}$ & $8 \mathrm{~m}^{2}$ & $\begin{array}{l}\text { Inca y Desarrollo Local } \\
\text { con restos indígenas } \\
\text { posteriores y mezcla de } \\
\text { componente con activi- } \\
\text { dades modernas (s. } \\
\text { XIX y XX). }\end{array}$ \\
\hline
\end{tabular}


la aguada cubriendo un espacio amplio adecuado para fines habitacionales.

Conjunte $\bar{l}(\mathrm{C}=1)$ : Seis bodegas subcuadrarguiares apegadas a un afloramiento rocoso. En el alto del afloramiento se destaca una típica estructura inca curvada agregada a una saliente rocosa a modo de avistadero y/o estructura ritual, la cual domina el asentamiento caracterizado por su dispersión.

Conjunto 2 (C-2): Es la estructura más amplia de forma arriñonada, con una bodega en el extremo norte. Presenta muros rectos y curvados sin argamasa, con un acceso modificado junto a una piedra de moler, cercano al afloramiento rocoso del conjunto anterior (Figura 10). A juzgar por su permanencia en el tiempo este recinto se reocupó por pastores, mineros y arrieros, los cuales han recolocado algunos tramos de los muros, quedando la bodega en un sector no modificado. De estas reocupaciones provienen restos de vidrios, latas y loza. Sin embargo, en su interior se localizó un depósito prehispánico con fragmentos de artefactos y fogones, advertidos a través de un suelo carbonoso variable entre 20 y $40 \mathrm{~cm}$ de profundidad. En el estrato alto compuesto de fogones y en la base subyacente con cenizas claras, se ha reconocido cerámica prehispánica de diversas épocas y abundantes restos de mineral de cobre, los cuales sumados a la escoria, permiten postular la presencia de una ocupación minera tanto subactual como prehispánica. En un caso se identificó un fragmento negro pulido pre inca, común en San Pedro de Atacama.

Conjunto 3 (C-3): Es un recinto rectangular con muros anchos construidos con la técnica de doble hilera de gruesos bolones pegados con argamasa de barro, con alteraciones en el ángulo sur-este (Figura 10). En su interior se observan muros modificados recientemente para alojamiento y cocina. En el sector perturbado se puede apreciar una estructura como bancada o poyo apegada al muro original. Las reocupaciones recientes limpiaron los pisos originales.

Conjunto $4(C-4)$ : Se trata de una bodega subcuadrangular con acceso orientado a los conjuntos 1 y 2 , con un trazado ancho de muros.

Conjunto 5(C-5): Es una bodega aislada de plan- ta inka o trapezoidal, deformada como la mayoría de los recintos por la caída de muros.

Conjunto 6(C-5): Es otra bodega sin argamersa de formato inca, de planta subcuadrangular con ac* ceso desde el conjunto 5, esta vez agregada a un afloramiento rocoso.

Conjunto 7(C-7): A unos $27 \mathrm{mt}$ del conjunto $3 \mathrm{se}$ ubica una aguada preparada con una estructura de bloques. La relación entre el recurso de agua y la construcción del asentamiento es evidente y hasta allí alcanza el área de vestigios culturales arqueológicos. Cerca de la aguada hay una estructura muy perturbada y un pequeño recinto circular $(\mathrm{C} 8)$.

El análisis de los restos culturales señala que este sitio pudo originarse en tiempos preincaicos, pero fue intensamente utilizado y reconstruido durante etapas posteriores, incluyendo reocupaciones durante los siglos XIX y XX. Se han observado tiestos café alisados, gris y café alisados, café estriados, rojo violáceos y café pulido, junto a percutores, preformas bifaciales, cuchillos asimétricos, puntas de flechas, lascas y láminas modificadas, palas plaquiformes y desecho de talla de cuarzo, sílice, calcedonia, obsidiana y basalto.

El análisis de los contextos estratigráficos y superficiales sumariados de todos los sitios establecen las siguientes recurrencias diagnósticas. Son frecuentes los registros de huesos de camélidos adultos vinculados con el uso de caravanas y consumo local en los asentamientos mineros ( $\mathrm{Ab}-38$, Ab-22 / S-3, Ab-44 A, Ab-36, Ab-42, Ab-20). Los registros de fecas (Ab-38, Ab-20 y otros) indicarían que las llamas permanecían en el área y desde aquí movían cargas hacia los locis de fundición y/o talleres localizados en las aldeas del Loa y tal vez en aquellas de Atacama. La presencia de mineral de cobre y turquesas indican una cerrada relación con los recursos locales (Ab-38, Ab-44A, Ab-43, Ab-20, Ab-35, Ab-20).

La cerámica roja pulida y bruñida, con preferencia al exterior, se reconoce dentro de los patrones incas locales, en la mayoría de los sitios vinculados con la mina prehispánica (Ab-38, Ab-22, Ab44, Ab-36, Ab-43). La escasa presencia de cerámica negra pulida clásica (Ab-38 y Abra-33 re- 
cinto $\mathrm{C} 2$ ), sugiere una ocupación pionera más temprana orientada a la evaluación minera con apoyo de recursos locales (presencia de palas y puntas de proyectiles). La cerámica local (Tradición Loa) de la familia Roja Violácea y Dupont, de data temporal preinca e inca, se encuentra en la mayoría de los sitios del entorno de la mina prehispánica (Ab-38, Ab-22, Ab-38, Ab-36, Ab-43, Ab-35). Registro de tiestos cerámicos grandes del patrón Loa, para acumular agua, usados en la mayoría de los campamentos (Ab-38, 36, 22, y otros), recuerdan similares funciones detectadas en la mina Cerro Verde/Caspana (Uribe y Carrasco en este volumen).

La presencia de martillos con restos de estériles y fragmentos de turquesa también se representa en la mayoría de los sitios. Es notable la ausencia de crisoles y lingoteras, al tanto, la escasa presencia de escoria $(\mathrm{Ab}-33)$ y un mínimo resto de cobre fundido (Ab-44) indicarían escasas labores de fundición local. Plataformas o canchas rectangulares tanto en las pendientes de extracción como en las estructuras de residencia y labor se han constatado en todos los asentamientos y campamentos. Dada la escasez de recursos alimentarios locales se identificaron restos provenientes del valle del Loa en la mayoría de los asentamientos y campamentos de labor: madera, semillas de algarrobo y chañar, maíz, llamas y otros.

\section{El proceso extractivo de la mina prehispánica Abra}

Los estudios sobre minas prehispánicas son escasos y estos suelen abordar los atributos paleotecnológicos y productivos, sin detallar la compleja cadena del proceso minero-metalúrgico en sus contextos culturales, ambientales, socioeconómicos y políticos (Bray 1985, Lechtman 1979 y 1984, Shimada y Merked 1991). No es mucho lo que sabe sobre los métodos de explotación, las técnicas de extracción y preparación a nivel de pre fundido, a raíz de las reocupaciones motivadas por los incas y principalmente por los laborios españoles, oportunidad en que se ocultaron para evitar la apropiación no exenta de apremios ilegítimos (Lechtman 1988, Lozano de Machuca 1992). Suelen ser de escalas reducidas en donde los óxidos de cobre se sitúan superficialmente, interviniéndose a través de trincheras estrechas y túneles poco profundos, siguiendo vetas con implementos de extracción limitados al uso manual de martillos y palas líticas (Shimada 1994, Bird 1979). En los casos de afloramientos de turquesa en terrenos planiformes se advierten socavados de no más de 4 a $5 \mathrm{~m}$ de diámetro, rodeados del material estéril en sus contornos con restos de los desechos percutidos derivados de la separación de los núcleos azulados de interés. Minas de esta naturaleza se identificaron en el límite de la II y III Región (tierras altas), cerca de las perforaciones de exploración llevadas a cabo por CODELCO por el año 1997 a cargo del geólogo Hans Niemeyer. El área de las extracciones se asocia a un conjunto de grandes estructuras residenciales y de labor. con alta frecuencia de cerámica pulida pre incaica del patrón S.P. de Atacama, descubierta durante la filmación del Camino Inca (Archivo Audiovi-sual "Al Sur del Mundo"). Las observaciones a través de la "ruta de la turquesa" (Camino del Inca) entre la III y II Región permitieron identificar extracciones socavadas y estrechas galerías para el acceso de un hombre no más allá de las vetas.

En el Abra se observan grandes socavados constituyendo socavones expuesto a la luz solar (Figura 3). Aquí debieron aplicarse faenas con martillo, barretas, palas y capachos para sacar el mineral seleccionado. Dada las limitaciones tecnológicas los socavados no podían ser muy profundos con el fin de obtener claridad y airamiento suficiente. De acuerdo a Sancho de la Hoz (1938 [1534], en Angiorama 1999: 75):

"no tienen luz alguna, ni más anchura que para entrar una persona agachada y hasta que esta no sale no puede entrar ningún otro" [...]"otras minas esparcidas por toda la tierra a manera de pozos profundos como de la altura de un hombre, en cuando puede el de abajo dar la tierra al de arriba y cuando las cavan tanto que ya el de arriba no puede alcanzarla lo dejan así y se van a hacer otros pozos."

Hallazgos de minas específicas se han planteado para la Puna Atacameña y Valles Transversales chilenos (Boman 1908, Iribarren 1971, Latcham 1936 y 1938, Bird 1979, Núñez 1987). No obstante, no siempre se han documentado en el norte de Chile los medios de producción y las estructuras de servicios, incluyendo los asentamientos aso- 
ciados. Por otra parte, es posible que los dos mineros hallados con martillos, barretas de madera y capachos de cuero de guanaco en Huantajaya (I Región) sean excepciones tan notables como el mismo "Hombre de Cobre" en términos de registros funerarios (Brown y Craig 1994).

En el caso del Abra, el proceso metalogenésico permitió concentraciones de minerales que afloraron con los colores cupríferos fáciles de advertir durante las exploraciones prehispánicas (Barba 1877). La mena es el mineral útil, el que se separa de la ganga o material desechado a través del proceso de extracción y selección. De modo que aquí se plantearon etapas de prospección, evaluación, selección de vetas, extracción. selección de mineral, trituración, molienda y concentración del material esencial separado del estéril. Para tales tareas, a diferencia de las labores agropecuarias, se requiere de instalaciones residenciales y campamentos fijos orientados a desarrollar altas inversiones de trabajo exigente, en un medio inhóspito, alejados de los recursos de valles y por lo tanto, al interior de un régimen laboral planificado, en donde casi todos los recursos provienen de un apoyo logístico externo conducido en este caso por la élite local y los funcionarios incas.

La alianza inca-élite local habría permitido el incremento de los obrajes mineros en gran escala, como el Abra, basado en la organización de la mita proveída tanto de los asentamientos aldeanos del río Loa como en menor cuantía de la cuenca de Atacama, de acuerdo a la evidencia cerámica. Es decir, con escasa cerámica inca cuzqueña o importada, reiterando aquí el patrón de manufactura predominantemente local, tal como se ha probado en los asentamientos de Caspana (Uribe 1999). Las instalaciones en torno a la mina se observan correlacionadas como parte de un sistema único, en donde la presencia de similares martillos, patrones arquitectónicos y cerámica, otorgan un carácter tecnológico homogéneo en términos de ocupación del espacio y procedimientos aplicados, sincrónico al tiempo en que la administración inca interfiere entre las élites locales. El proceso se caracteriza por los siguientes pasos a partir de la ubicación visible de las vetas (turquesa):

Etapa 1: Extracción de mineral con martillos so- bre las vetas expuestas y su acumulación en los terraplenes o canchas asociadas a sectores con alta frecuencia de martillos (sectores 1, 2, 3, 4, 5 y 6), extendidos en la pendiente de la quebrada. Cobo (1964) corrobora que el mineral sacado de la mina se dispone en corrales o canchas, junto a la mina, y allí a golpe de martillo, con plena claridad, lo valioso se separa de las "piedras inútiles." Se comprende que las llamas y los cargadores con capachos deben descender a las canchas y campamentos con el material muy seleccionado, varias veces al día, puesto que llamas y hombres o mujeres no cargan más que 40 a 80 kilos cada vez respectivamente. Los depósitos de estériles no compactos, fueron sacados con capachos cargados a la espalda (Bird 1977). Aquellos confeccionados con la estructura tradicional preincaica, esto es, con maderos curvados y trama vegetal o textil, suspendidos con faja desde la frente, perduraron entre laborios cupríferos de Cobija aún durante el siglo XIX (D’Orbigny 1976: 935 lam. 30).

Como se trata de un sector de alta pendiente se dispusieron siete muros lineales de contención de aluviones sobre las hoyadas donde se extraía el mineral. Aquí no se detectan martillos, no obstante, en los sectores 7 y 8 , cercanos a las vetas, se ubicaron múltiples martillos en planos y pendientes junto a las minas específicas, rodeados de desmonte estéril (aspecto blanquecino), en donde se concentraron las labores de extracción, tanto prehispánicas, como posteriores, explicándose así la magnitud de los socavados.

Etapa 2: Acumulación en la cancha Ab-40 (sin martillos) por cuyo camino del patrón inca se trasladó el mineral al sitio Ab-36, en donde se procedió a reducir el mineral con martillos registrados in situ. En general, el mineral era dispuesto en dos canchas no alteradas por la erosión de las altas pendientes, para acumular allí el mineral e iniciar el martillado sobre las gangas estériles adheridas. La presencia de cerámica en las canchas, junto a martillos, sugiere consumo de alimentos y bebidas in situ, tal como se ha descrito para el distrito de Caspana, un énfasis en depósitos de líquido directamente vinculado con labores mineras (Uribe 1999).

Etapa 3: El mineral trasladado desde las canchas a los campamentos ubicados en el fondo de la 
quebrada ( $\mathrm{Ab}-38,37$ y 36) es depositado en terraplenes con martillos asociados a mineral y partes estériles desprendidos. De acuerdo a la similitud de los recintos, canchas, martillos y cerámica, se postula una correlación entre los sitios 38,37 y 36. Está claro. por la ubicación de fogones, huesos y tiestos cerámicos, que en estos campamentos de martillado se consumían alimentos, en especial: maíz, algarrobo, chañares y carne de llamas, a juzgar por la evidencia en superficie y en los test. Esto es válido para los tres sitios con recintos estructurados bajo la mina. Sin embargo, la mayor actividad residencial en términos de alojamiento, martillado, bodegaje, cocinería y mantención de llamas se concentró en el gran poblado Ab-36.

Etapa 4: Las cargas de mineral seleccionado se conducen hacia los pueblos-cabeceras ubicados en el río Loa y quizás de la cuenca de Atacama, en donde se procedía a las tareas de fundido (combustible de árboles locales) y/o tallado de cobre de color como artesanía de ornato y ritualístico. La presencia de escaso cobre fundido en los sitios del Abra indica eventuales pruebas de pureza, pero la ausencia de crisoles y lingoteras, sugiere más bien que el fundido ocurrió en áreas de algarrobales a nivel del Loa y cuenca de Atacama, siguiendo el patrón previo (hornos localizados en hábitat estables). Dada la cercanía de las aldeas estables del río Loa, lo más probable que la etapa de fundido y lingoteado haya ocurrido fuera de las menas del Abra. Este sería el modelo más esperado de acuerdo al traslado del mineral desde las minas de Capillitas a la región de los algarrobales durante el siglo XIX en el N.O. Argentino (L.R. González 1994).

En suma, la mina del Abra responde a las etapas de extracción y selección de mineral más productivo, previo intenso proceso de martillado. Estas labores fueron permanentes y se realizaron con mineros locales de larga experiencia, concentrados aquí por el sistema de mitas provenientes desde sus aldeas cabeceras, unidos por rutas caravaneras entre el Loa y el Abra.

\section{Areas de labores específicas y clasificación de martillos}

De acuerdo a la presencia de martillos y minera- les se identificaron siete sitios de labor (Núñez Ms-b) en Ab-40, 39, 22, 36, 37, 38 y 43, asociados a canchas, restos alimentarios, cerámica incalocal, muros de contención, vetas expuestas, restos de gangas, yunques líticos planiformes, restos de platos y cántaros para bebidas y desechos de martillos fracturados.

Considerando estos sitios se registraron 387 martillos, los que fueron clasificados de acuerdo a sus atributos morfológicos, zonas de uso, localización de la escotadura de enmangue y marca pulimentada del roce del mango sobre el percutor. Las rocas seleccionadas son duras y de origen local, colectadas de depósitos aluviales, constituyendo nódulos alargados y cortezados (toba, diorita, andesita y granito).

Tipo I: Cuerpos alargados relativamente estrechos con la escotadura y marca de enmangamiento en la zona superior o proximal. La zona distal es alargada con desprendimiento en el extremo por el percutido.

Tipo II: Cuerpos alargados y relativamente estrechos con la escotadura y marca pulida del roce del mango en el centro de la pieza. Ambos extremos presentan desprendimientos por percusión, observándose desgastes en sus extremos hasta constituir cuerpos agotados.

Tipo IIIa: Cuerpos anchos de secciones planas o extendidas con la escotadura y marca de pulido del enmangamiento en el centro de la pieza. Ambos extremos están activos con desprendimientos por percusión y tendencia a agotarse por fracturas.

Tipo IIIb: Cuerpos anchos de sección plana o extendidas con la escotadura y marca de pulimento del enmangamiento en el sector superior proximal no usado. El cuerpo activo distal presenta desprendimiento por percusión.

Tipo IV: Cuerpos estrechos y alargados con escotadura y pulido por roce del enmangamiento en el centro de la pieza. Ambos extremos han sido percutidos con distintos avances de desprendimientos.

Tipo V: Percutores de mano sin enmangamiento 
con dos a tres lados percutidos vinculados con funciones de golpe más específicos para extraer estéril.

Tipo VI: Grupo reducido de martillos grandes de forma trapezoidal con escotadura y roce pulido del enmangamiento en el centro de la pieza.

Es claro que en todos los sitios los tipos I y II son los más populares seguidos a distancia por los tipos III a, b, IV y V. Parece natural que los martillos más pesados eran usados ocasionalmente de acuerdo a su baja frecuencia. Queda fuera de duda que la alta frecuencia del uso de martillos, indica que la labor de extracción fue la más dominante junto a la percusión sobre la ganga estéril para separar el material de color (Tabla 2).

En el caso específico del sitio Ab-22 o área de la mina, no asociado a estructuras, el total de martillos es mayoritario comparativamente y alcanza a 362 implementos, en donde los tipos I y II son dominantes, siendo frecuentes además en todos los sectores (Tabla 3). Por otro lado, la distribución de los tipos más populares en todos los sitios de la mina y su entorno hablan a favor del desarrollo de un sólo evento laboral, simultáneo en todos los sectores, notándose más actividad en aquellos con mayor estabilidad para la aplicación del martillado en la pendiente (sector 5 y 6 )(Tabla $3)$.

Los martillos varían de acuerdo a sus funciones en peso y volumen, además al mayor o menor uso. Considerando sus modelos más completos se desprende que los martillos pesados I y II o de golpe más contundente, son comunes en todos los sectores, con medidas dentro de un patrón medio. No

Tabla 2. Tipología, frecuencia y distribución de martillos

\begin{tabular}{|c|c|c|c|c|c|c|}
\hline Tipología & Ab-22 & $A b-38$ & Ab-36 & $A b-43$ & Ab-39 & Totales \\
\hline $\begin{array}{l}\text { Tipo I: escotadura superior, extremo } \\
\text { distal activo. }\end{array}$ & 91 & 4 & 5 & $\begin{array}{c}1(\mathrm{E}-\mathrm{I}) \\
1\end{array}$ & 2 & 104 \\
\hline $\begin{array}{l}\text { Tipo II: escotadura central. } \\
\text { doble extremo activo. }\end{array}$ & 113 & 2 & 5 & 3 & 3 & 126 \\
\hline $\begin{array}{l}\text { Tipo IIIa: escotadura central en cuer- } \\
\text { po ancho. }\end{array}$ & 14 & & & & 1 & 15 \\
\hline $\begin{array}{l}\text { Tipo IIIb: escotadura superior cuer- } \\
\text { po ancho. }\end{array}$ & 40 & 1 & & & & 41 \\
\hline $\begin{array}{l}\text { Tipo IV: escotadura superior con dos } \\
\text { extremos activos. }\end{array}$ & 26 & 1 & & 1 & & 28 \\
\hline $\begin{array}{l}\text { Tipo V: sin escotadura (martillo de } \\
\text { mano). }\end{array}$ & 20 & 2 & & & & 22 \\
\hline $\begin{array}{l}\text { I ipo } V \mathrm{I} \text { : con escotadura central en } \\
\text { grandes cuerpos trapezoidales. }\end{array}$ & 4 & 1 & & & & 5 \\
\hline $\begin{array}{l}\text { Гipo VII: miscelánicos, fragmentos } \\
\text { no clasificados. }\end{array}$ & 44 & & & 2 & & 46 \\
\hline Totales & 352 & 11 & 10 & 8 & 6 & 387 \\
\hline
\end{tabular}


Tabla 3. Sitio Ab 22: distribución de martillos por sectores

\begin{tabular}{llllllllll}
\hline Tipo & $\mathbf{1}$ & $\mathbf{2}$ & $\mathbf{3}$ & $\mathbf{4}$ & $\mathbf{5}$ & $\mathbf{6}$ & $\mathbf{7}$ & $\mathbf{8}$ & Totales \\
\hline Tipo I & 15 & 9 & 12 & 10 & 15 & 12 & 8 & 10 & 91 \\
Tipo II & 12 & 19 & 16 & 12 & 22 & 19 & 10 & 13 & 123 \\
Tipo IIIa & 4 & 1 & - & - & 4 & 2 & - & 3 & 14 \\
Tipo IIIb & 1 & 8 & 7 & 8 & 5 & 5 & 5 & 1 & 40 \\
Tipo IV & - & 3 & 6 & 4 & 4 & 5 & 4 & - & 26 \\
Tipo V & - & 4 & 3 & 1 & 4 & 4 & 3 & 1 & 20 \\
Tipo VI & 1 & - & 1 & - & - & 2 & - & - & 4 \\
Tipo VII & 3 & 7 & 3 & 3 & 11 & 6 & 11 & - & 44 \\
\hline Totales & 36 & 51 & 48 & 38 & 65 & 55 & 41 & 28 & 362 \\
\hline
\end{tabular}

obstante, los cuerpos más pesados manipulados por una persona (tipo VI) (Bird 1979), para acciones de mayor demolición, son escasos, al igual que aquellos de menor uso y pequeños (no enmangados) aplicados directamente para labores más delicadas en torno a la extracción de turquesa desde gangas más complicadas (Figura 1).

Para reconstituir su manufactura se cuenta con fotos que ilustran las técnicas de enmangamiento original. En efecto, a fines del siglo pasado se descubrió el cuerpo de un minero pre incaico colapsado por un derrumbe en una galería del área de Chuquicamata (Figura 12). Entre su equipo había un capacho de carga (cuero), minerales y martillos completos datados por los $1400 \pm 40$ años $\mathrm{AP}$, equivalente a 550 años DC, actualmente exhibido en el Museo Americano de Ciencias Naturales de la ciudad de New York (Bird 1979) (Figura 13). Por otro lado, Latcham (1938) publicó dos especimenes completos de Chuquicamata y mina San Bartolo, cerca de San Pedro de Atacama. Con estas colecciones a la vista fue posible reconstituir el procedimiento de enmangamiento, puesto que los tipos aquí definidos coinciden con las técnicas y materiales presentados por Bird (1979). Primero se obtiene un nódulo cortezado semicilindrico de roca dura y se percute una faja más o menos central para lograr la escotadura, en donde se ajustará la rama verde de algarrobo o chañar de un espesor entre 1 a $2 \mathrm{~cm}$ de diámetro dispuesta remojada en torno a la escotadura, entrecruzándose con tensión en el mango proximal con un amarre de cuero húmedo. Luego con un tiento mojado se fija la rama al cuerpo del martillo y con otros perpendiculares hasta la base del martillo, armándose un soporte trasero que le da más seguridad manteniéndolo fijo al mango.

El registro de martillos pre incas como los de Chuquicamata, Huantajaya, San Bartolo y el Abra de data inca-local, se reconocen en minas específicas, pero también de un modo aislado, en faenas de exploración, tal como se registró entre la serranía cuprífera de Tuina. Estos martillos suelen pesar desde unos 500 a 3.000 gr y funcionan a nivel de vetas o como machacadores siendo también comunes en la literatura trasandina (L. R. González 2000).

\section{Evaluación cronológica del Abra}

La naturaleza prehispánica tardía de la frecuente cerámica roja violácea y roja pulida bruñida, de 
filiación local e inca (Uribe 1999), además de los martillos pre incas y el patrón arquitectónico inca, presuponen un rango de tiempo de los 1300 a 1500 años DC para el sistema extractivo de la mina del Abra (Bird 1979, Uribe 1999, Uribe y Carrasco en este volumen). Para determinar el marco cronológico se practicaron tres test cronoestratigráficos. En el sitio Abra 38 (Test-1, Figura 6) se ubicaron dos test en sectores diferenciados. El test1 a $10 \mathrm{~m}$ al NE del recinto principal, en el exterior, en un sector superficial cubierto con restos de mineral de cobre, martillos y cerámica $(50 \mathrm{x}$ $50 \mathrm{~cm}$ ). El estrato I es un depósito superficial con semillas de chañar, coprolitos y cerámica estriada café. El estrato II es semicompactado con huesos de camélidos y concentraciones de carbón (fogones). De este nivel se obtuvo la siguiente datación (radiométric standard): edad convencional Beta 113505 (carbón): $880 \pm 180$ AP (11 cm de profundidad), con una edad calibrada año calendario de 1105 a 1285 DC.

Diversos estudios aceptan el arribo de la colonización inca al norte de Chile antes de los 1470 DC. Incluso, las dataciones C14 logradas en el centro-norte del país dan cuenta de fechas aún anteriores entre los 1300 a $1400 \mathrm{DC}$. Como en este test no se registraron restos netamente preincaicos y los registros superficiales (p.e. martillos) pueden afiliarse a niveles incas y preincas, sólo resta aceptar que esta ocupación ocurrió por los 13001400 DC de acuerdo a su contexto cultural y edad máxima aproximada (ver Schiappacasse en este volumen).

El test 2 (Figura 6) se ubicó un sector con restos de fogones y huesos de camélido en superficie a unos $140 \mathrm{~cm}$ de la estructura más cercana en dirección NE. El estrato I es un depósito único, disgregado, con huesos de llamas, vegetales, coprolitos y cerámica café lisa y estriada, dispuesto como el test anterior sobre un piso amarillo estéril muy compacto. De la base del depósito $(14 \mathrm{~cm})$ se registraron carbones de leña correspondiente a un fogón lenticular restringido. El resultado del análisis fue el siguiente (radiometric standard): edad convencional Beta 113506 (carbón): $510 \pm$ $70 \mathrm{AP}$, con una edad calibrada año calendario del orden de 1305 a 1495 DC. Esta datación es algo más tardía que la anterior, sugiriendo que la ocupación dentro de la estructura y sus márgenes se- ría algo posterior, pero se ajusta bien al techo del tiempo de la ocupación propuesto por los 1400 años DC.

La tercera muestra procede del gran poblado $\mathrm{Ab}$ 36 , organizado por los incas (p.e. nicho trapezoidal) y cerámica roja pulida-bruñida (Test 3, Figura 5). Tanto los martillos como los tiestos locales pertenecen a la tradición tardía y media del Loa y S.P. de Atacama. El test se localizó en el extremo SE del poblado, en el ángulo de un gran recinto, en donde se detectó superficialmente restos de ceniza, huesos de camélido y cerámica roja pulida inca-local. El test fue del orden de $30 \times 30$ $\mathrm{cm}$, con una profundidad máxima de $23 \mathrm{~cm}$. El depósito es homogéneo con residuos de ceniza, carbones y alta frecuencia de restos de un camélido adulto, consumido y desechado en el rincón SE del recinto. La muestra de carbón estaba dispersa sobre el piso compacto, sincrónico al consumo del camélido durante el inicio de la ocupación. El estrato I es un depósito único con relleno eólico superficial mezclado con restos culturales (p.e. cerámica y huesos de camélido adulto). De este nivel se obtuvo una datación a base de carbón (18$20 \mathrm{~cm}$ ) (radiometric standard), edad convencional Beta 113507 (carbón): $290 \pm 50$ AP, correspondiente a una edad calibrada año calendario del orden de 1475 a 1675 DC.

Este rango de tiempo se relaciona, en su sigma mínimo, con la época más tradicional (etnohistórica) adjudicada a la expansión inca en el actual territorio de Chile. De ser válido su rango tardío la ocupación habría pervivido durante la temprana colonia española, sin embargo, la ausencia de rasgos europeos habla a favor de una plena sincronía con los asentamientos inca-local, acorde con fase post Quinchamale del Loa Superior cronologizada entre los 1470 a 1535 DC (Berenguer 1994).

En relación a la cronología post inca se identificaron vestigios de fundición junto a la iglesia de Conchi Viejo, donde se ha documentado la localización de un importante centro minero-metalúrgico perteneciente al s. XVIII, que incluía la mano de obra local, de modo que las vetas de las quebrada de la Aguada y las Ruinas no parecen haberse explotado intensamente después de los episodios inca-local. 
Hasta ahora no se habían documentado ocupaciones extractivas prehispánicas, fuera del Loa, constituyendo los sitios del sistema El Abra, los primeros en afiliarse por su cerámica, martillos y estructuras residenciales y de labor, a una etapa inca-local concreta. Aunque todos los sitios del sistema son más o menos sincrónicos, bajo la esfera del dominio inca, se propone una secuencia tentativa en donde las primeras labores extractivas habrían ocurrido en los campamentos Ab-37 y 38 , más cercanos a la mina, en un rango inicial de los $1105(?)$ a 1305 DC, hasta los 1285 a 1495 DC (últimos eventos en Ab-38). El clímax productivo y demográfico habría ocurrido posteriormente, durante el poblado principal Ab-36, asociado a indicadores culturales homólogos a los sitios anteriores, datado entre los 1475 a 1675 DC. Dada la ausencia de restos europeos, este sitio estuvo en uso entre los 1300 a los 1475 DC. La cerrada correlación entre las fechas $\mathrm{C} 14$ recibidas y los contextos sincrónicos inca-población local vienen a ratificar la colonización minera entre los 1300 1475 años DC fuera de los hábitats apegados a los valles fluviales, como el resultado de una eficiente política de incremento de la producción minera administrada por el régimen incaico.

\section{Evidencias mineras en el distrito Chuquicama- ta-Tomic}

De acuerdo a esta propuesta existió una expansión minero-metalúrgica hacia locis óptimos antes y con los incas, fuera de los ámbitos vallesteros, alejados del Camino del Inca, partiendo desde las aldeas agropecuarias del río Loa y cuenca de Atacama. La escasa exploración arqueológica en distritos mineros enclavados en territorios inhóspitos no ha posibilitado situar campamentos de grupos de tareas vinculados directamente con los laborios extractivos. El caso ChuquicamataTomic es por ahora otro indicador de nuevas fuentes que podrían investigarse más sostenidamente desde una visión teórica orientada a identificar patrones de trabajo minero distintos a las modalidades domésticas más tradicionales de las cabeceras aldeanas. En el distrito referido se situaron varios sitios prehispánicos descritos a continuación (Núñez 1999 Ms):

Chu-2: Se ubica a unos $1500 \mathrm{~m}$ al NO del actual yacimiento Chuquicamata, a $3.050 \mathrm{~m}$.snm, cerca- no a una postación eléctrica que cruza el sector, vinculado a afloramientos cupríferos locales. Corresponde a un campamento minero pre-incaico compuesto por 10 recintos pircados con contornos semicirculares abiertos al este, a modo de "medias lunas", con depósitos de desperdicios levemente estratificados.

En la superficie se encontraron puntas de flechas de cuarzo y obsidiana y otros artefactos reducidos de cuarzo y calcedonia local. A juzgar por la identificación de fragmentos de conchas del pacífico y erizos, se acepta que estos grupos se desplazaban tras recursos mineros y de subsistencia en una amplia escala geográfica. También utilizaban rocas locales de andesita y basálto para la confección de martillos y de palas similares a las de uso agrícola, pero esta vez aplicadas en labores mineras (Bird 1979, Uribe y Carrasco en este volumen). La presencia de azurita muy pura y molibdeno, se correlaciona con la extracción de afloramientos ubicados en el suroeste del sitio (Figura 14).

El hecho de que este campamento se situe en un territorio con vetas expuestas, pero inhóspito, sin recursos de subsistencia, demuestra su finalidad minera durante el Período de Desarrollo Regional Avanzado, constituyendo el primero reconocido en el sector de Chuquicamata, aunque no es segura su relación con las evidencias del "Hombre de Cobre" (Bird 1979). Se identificaron entre las estructuras y rutas distintas tradiciones cerámicas involucradas con asentamientos preincaicos del valle del Loa: Dupont, rojos pulidos, café alisada y roja violácea. Desde la cuenca de Atacama parecen provenir tiestos grabados-punteados y negros o café pulidos interiores tardíos. El componente altiplánico negro sobre rojo y más específicamente del complejo Toconce-Mallku (Aldunate et al. 1986), es homólogo a otros pucos del Altiplano Meridional, cronologizado durante su clímax por los 1300 años DC (Aldunate y Castro 1981, Aldunate et al. 1986, Uribe 1977).

Chu-4: Asentamiento ubicado a ambos lados del camino de acceso por el borde occidental de la cuenca Tomic, compuesto de 13 recintos pircados sin argamasa, localizados en la pendiente que domina la depresión. Los recintos se concentran más al este del camino, incluyendo algunos al oeste, con un típico patrón disperso, con protección na- 
tural al pie de los cerros de occidente y amplias visuales hacia la depresión del oriente (hay recintos alterados cuando se abrió el acceso). Llama la atención la ausencia de restos culturales superficiales (p.e. cerámica), a pesar de que su formato es indígena. Siguiendo su patrón formal y distribucional se sugiere una ocupación inmediatamente posterior al sitio Chu-1. En efecto, en el núcleo de este campamento se advierte un recinto de planta trapezoidal inca, asociado a un depósito rectangular agregado y varias trojas circulares, rasgo advertido también en la quebradilla del sector oriental. Puesto que estos sitios prehispánicos se han vinculado con campamentos de tareas mineras y tráfico caravanero, se procedió al reconocimiento del borde N.O. (Núñez 1998 Ms y Ms b).

Chu-7: Recinto pircado asociado a otro más disgregado complementado de un socavado subrectangular que sirvió como espacio de refugio. Se ubica a unos $500 \mathrm{~m}$ al $\mathrm{N}$ del tendido eléctrico conducente a mina Tomic ( $22^{\circ}-07^{\prime}-41.4^{\prime \prime} / 68^{\circ}$ 54'-47.4"). La presencia de cerámica torneada colonial hispánica (botija) indica su época, aunque hay restos de tiestos de tradición indígena. Se trataría de un refugio temporal del tráfico hacia la costa conectada con la implantación española a través del rumbo Quillagua-boca del Loa y/o Cobija.

Chu-8: Por las rutas prehispánicas paralelas al tendido eléctrico con rumbo al $\mathrm{O}$, se identificaron dos recintos separados por unos $300 \mathrm{~m}\left(22^{\circ}-07^{\prime} 0.09^{\prime \prime} /\right.$ $68^{\circ}-55^{\prime}-27,3$ "). Desde aquí bajan hacia el área de mina Tomic, marcada con hileras de piedras. Estas rutas pasan por un Abra $\left(22^{\circ}-07^{\prime}-00.9^{\prime \prime} / 68^{\circ}\right.$ $\left.55^{\prime}-40.8^{\prime \prime}\right)$, en donde se registró un topu prehispánico fundido en cobre con cabezal en forma de espiral (Núñez 1998 Ms a).

Chu-9: Siguiendo el tendido eléctrico a minera Tomic, como punto de referencia, a unos $2.500 \mathrm{~m}$ al $\mathrm{N}$ se identificó el mejor trazado de rutas caravaneras del patrón de llamas cargueras de data prehispánica. Estas se orientan con rumbo $110^{\circ}$ a $120^{\circ} \mathrm{SE}$ en dirección del borde oriental de la cuenca Tomic. En este trazado, una vez que se domina la cuenca del Abra y Chu-5 (pampa Cere), ocurrió un típico ritual andino del tráfico caravanero de larga distancia, es decir, ofrendas dispuestas en las rutas (GPS $22^{\circ}-08^{\prime}-48.9^{\prime \prime} / 68^{\circ}-53^{\prime}-22.0^{\prime \prime}$ ). Es un acumulamiento artificial de rocas como gran marca o apacheta abatida(?) en donde se depositan piedras en un espacio nuclear de la ruta. Al observar esta concentración se aprecian cerámiças rotas y ofrendas de miles de fragmentos de cobre de color, cubriendo un área de $20 \times 20 \mathrm{~m}$, aunque el sitio total lo triplica. El registro de tiestos cerámicos pertenecientes a una misma pieza fragmentada deliberadamente en el ceremonial se advierte en varios casos. En el locus se registraron además diversas clases de artefactos líticos: núcleos y preformas finas rebajadas, dominando percutores vinculados con prácticas mineras (Figuras 15 y 16 ).

La asociación entre rutas paralelas de $\mu_{i}$ imidas por el uso intenso, con materiales arqueológicos es directa, con registros de cerámica doméstica, conchas del Pacifico (ostión) y cerámica decorada del patrón altiplánico con motivos negro sobre base rojiza. Otro rasgo típico es la extracción de piedrecillas y bloques pequeños para amontonarlos en leves montículos, observados a lo largo de las rutas. De acuerdo a similares evidencias ubicadas en torno a las rutas prehispánicas de los altos de Pica y siguiendo la explicación etnográfica, estos acumulamientos es el resultado de rogativás de cada caravana. A unos $30 \mathrm{~km}$ al W de estas rutas y con el mismo rumbo se sitúan los geoglifos monumentales de Chug-Chug, de estilo tarapaqueño, cuyas rutas preincaicas de retorno provenien del Loa Medio y Superior y pasan por Chu-9, orientándose a Chug-Chug y Quillagua, donde se divide la conexión hacia la costa aledaña y Valles Occidentales de la I Región. Se trata, en consecuencia, de una ruta preincaica utilizada con el multipropósito de acceder a distritos mineros bajos, a los recursos forestales multiétnicos de Quillagua y costa aledaña. incluyendo la conexión tarapaqueña (Agüero et al. 1997). El desvío al norte está marcado con rutas, geoglifos y paskanas con cerámica pre inca y fecas de llamas, identificadas precisamente entre Quillagua y Guatacondo/ Pica.

La cerámica Hedionda permite una estimación cronológica correlacionada con el Alto Loa, del Intermedio Tardío (Uribe 1997). Similares fragmentos ubicados en la aldea de Quillagua (Téllez y Cervellino 1976) indican, por otro lado, la segura conexión caravanera entre los componentes 
cerámicos locales y altiplánicos. En cuanto esta cerámica altiplánica es común en las tierras altas del Loa y Altiplano Meridional y su presencia se integra al circuito caravanero con tráfico de minerales observados en Lipez (Nielsen 1997 y 1999 Ms, Aldunate y Castro 1981), todo conduce a sugerir que los circuitos caravaneros con énfasis en el acceso a locus mineralizados, conectaba al Altiplano Meridional con el Loa Superior y desde aquí articularon menas y recursos hasta el litoral, por las rutas apegadas al norte del cañón del Loa, asociadas a varias paskanas y senderos en proceso de investigación (Quillagua-boca del Loa). La interconexión entre las tierras altas y el litoral se confirma con la constante ubicación de restos de conchas tanto en estas rutas como en los recintos de Chu- 2 y 5 . Por otra parte, el hallazgo de idéntica cerámica altiplánica en Chu-2, vincula los sitios del área de estudio con un sistema de tráfico tierras altas-costa, en donde las labores mineras eran parte de un complejo tráfico de bienes múltiples (Núñez 1987 y 1994).

Las sendas salen del sitio Chu-9 hacia el extremo SE de las instalaciones de minera Tomic por el punto $22^{\circ}-08^{\prime}-004^{\prime \prime}$ / 68 $-54^{\circ}-42.7^{\prime \prime}$, pasando por una quebradilla con rumbo $120^{\circ} \mathrm{SE}$, continuando por la extensa pampa inclinada del sector oriental de Tomic, acercándose al sitio Chu- 5 y de allí al río Loa.

Chu-5: Se trata del asentamiento prehispánico más denso registrado con un total de 27 recintos (Figura 17). Predominan los recintos subcirculares con muros sin pegamento, generalmente abatidos y aglomerados entre sí con restos de mineral de cobre. Se emplaza al pie de una colina bien individualizada a unos $150 \mathrm{~m}$ al sur del camino del control de Mina Tomic. La presencia entre y dentro de los recintos de cerámica café alisada tardía similar a la descrita para el río Loa permite estrechar relaciones de interacción, apoyado por el rumbo de las rutas registradas. Por su carácter de paskana bien dispuesta fue reocupada en tiempos hispánicos (cerámica torneada) y posteriores. Este sitio está asociado directamente a un sistema de senderos llameros y troperos más recientes que se orientan al sur de Pampa Grama, hacia el área de Chiu-Chiu-Lasana, con un rumbo de $300^{\circ} \mathrm{NO}$. Ascienden al borde norte de la depresión o cuenca de Tomic, en dirección al distrito cuprífero del área. A unos $200 \mathrm{~m}$ al SW de este sitio, entre una pequeña abra, pasa otro sistema de senderos similares que bordea el derrubio y el camino de acceso a mina Tomic. contactado a unos $200 \mathrm{~m}$ al $\mathrm{N}$ de Chy-6. Estas futas se orientan a la Serranía del Inca, en donde se ubican los campamentos prehispánicos 2 y 4 , respectivamente (rumbo $305^{\circ}$ N.O.).

Chu-6: Es un conjunto de cuatro recintos pircados subcirculares asociados a nueve depresiones interpretadas como espacio de descanso de llamas cargueras (algo similar a los llamados revolcaderos de camélidos). Se sitúa a unos $1.000 \mathrm{~m}$ al sur del camino principal de acceso a la mina Tomic y a unos $3,5 \mathrm{~km}$ al oeste de Chu-5. Las huellas caravaneras que provienen del este se localizan a unos 70-60 $\mathrm{m}$ al $\mathrm{N}$ del sitio. La ausencia de restos culturales no ayuda a determinar su filiación cronológica.

Las ocupaciones identificadas se insertan en un medio desértico alejados de los recursos de agua, dando cuenta de un objetivo minero inequívoco asociado a ricos afloramientos cupríferos superficiales, que incluían tanto la materia prima para fundido como para aplicaciones de ornato (turquesa). Es decir, son colonias enviadas desde las aldeas estables del río Loa Medio y Superior. El inicio de la explotación minera habría ocurrido cerca del tajo abierto de la mina actual de Chuquicamata (Chu-1), en el campamento con estructuras asociadas a cerámica pre inca del patrón Loa Tardío y Ayquina-Toconce, incluyendo contactos con San Pedro de Atacama (900-1450 DC). Otra ocupación similar y aún de eventual tiempo inca se instaló al centro del borde de la depresión intermontana (Chu-4).

Estos grupos de tareas provienen de aldeas tardías y se desplazan por un sistema de rutas caravaneras que salen del sector Chiu-Chiu-Lasana por el sur de pampa Grama. Se introduce un ramal a Chu-5 que en su rol de paskana principal fue reocupado. El otro ramal se advierte por un paso cercano a Chu-5. Mientras la primera ruta se orienta hacia las minas prehispánicas del Abra, la segunda recorre el pie de la serranía al sur del camino de acceso a la mina, orientada a los sitios Chu-2 y 4. 
Las rutas y sus rituales detectados en los sitios 7,8 y 9 admiten que los rumbos caravaneros sobrepasaron el área mineralizada de la cuenca del Abra y serranía de Chuquicamata, orientándose a la colina sagrada de Chug-Chug y la vertiente homónima, ambos con geoglifos, orientándose la ruta a la costa aledaña del Loa por Quillagua, incluyendo el desvío a los Valles Occidentales del norte.

Por todo lo anterior, se propone el desarrollo de un sistema de ocupación minero-extractivo, con campamentos y rutas procedentes de las aldeas permanentes del río Loa Medio y Superior, orientados a la explotación de los distritos de Chuquicamata-Tomic-Abra, con conexiones con las tierras bajas, y el litoral durante etapas pre incas tardías e inca.

Hasta ahora no ha sido posible localizar la mina de Chuquicamata en donde se descubrió el asíllamado "Hombre de Cobre" de data preincaica (Bird 1979). Fuera de dudas, este único contexto laboral debería relacionarse con los eventos ocupacionales antes descritos, a pesar de que su datación es algo más temprana. Se trata de un joven corpulento con manos fuertes y uñas erosionadas por la labor, seleccionado para tareas extremas en la serranía cuprífera de Chuquicamata ( $c a .3 .000$ $\mathrm{m} . \mathrm{snm}$ ). Para los efectos del presente argumento, se trata de un minero que articula una labor de extracción distante de su núcleo aldeano. Es parte de una colonia o fuerza de tarea trasladada, que lo abandona una vez que polifracturado fallece bajo su galería a raíz de un eventual movimiento sísmico o tal vez de un accidente del trabajo propio de los derrumbes. Usa un trenzado compuesto por tres ramales delgados a cada lado y adornos textiles o tobilleras en los pies. Está cubierto sólo por una cobertor púbico tejido en faz de urdimbre sujeto a la cintura por una faja (Figura 18).

Puesto que con seguridad es un individuo que ejecuta una labor minero-extractiva, todo lo que posee debería iluminar la naturaleza de su misión algo anterior al Período de Desarrollo Regional Avanzado. El análisis de su contexto y de las fotos de fines del siglo pasado lo sitúan junto a una pendiente de la serranía de Chuquicamata. a unos $2 \mathrm{~m}$ de un pique. Luego fue trasladado a las instalaciones de una mina donde es fotografiado con sus objetos asociados, que dado el carácter inhós- pito del área, es imposible que esto no le pertenezca dada la carencia de sitios de otras clases: cestos, capacho de cuero, martillos y pala con mango de madera atado con cuero. La pala se ajusta a las clásicas lajas planiformes confirmándose el doble patrón de uso, tanto agrario como minero, tal como se ha propuesto para el área de Caspana (Uribe y Carrasco, en este volumen). Los martillos presentan mangos completos, es decir, con varas tensionadas a través de cuerdas de cuero que a su vez ajustan el percutor de roca (Figura 13). Se reconoce uno que está provisto de un percutor de gran tamaño, otros dos intermedios y uno más pequeño, relacionado cada uno con funciones seguramente distintas. Estos martillos son totalmente similares a los usados durante la etapa incaica en la mina del Abra, demostrando que la tradición minero-extractiva fue ya especializada antes del Desarrollo Regional Avanzado y obviamente antes de los incas, de tal modo que es cierto que ellos no proponen innovaciones en términos de tecnologías del trabajo minero.

\section{Conclusiones}

Se han destacado los logros paleometalúrgicos alcanzados por la sociedad andina del Centro-Sur al interior de un proceso de complejidad creciente a través de bienes de prestigio para las élites, $\mathrm{cu}$ yos orígenes se remontan por los 1200 años AC. En este sentido los recursos minero-metalúrgicos circumpuneños (cuencas del Loa y salar de Atacama) se reconocen muy potenciales, alcanzando su clímax durante la interacción Tiwanaku-poblaciones locales (600-900 DC) y más atenuadamente durante el Desarrollo Regional Avanzado (9001450 DC). Las labores de extracción, fundido, moldeado y orfebrería, incluyendo la aplicación y ritualización del cobre de color, constituyeron las tecnologías más complejas y prestigiosas, implicando especializaciones de oficio y tráfico caravanero de bienes de estatus controlados por las élites locales.

Dada la alta productividad y virtuosismo tecnológico de los bienes metálicos y aplicaciones de piedras preciosas localizadas en las cuencas de Atacama y Alto Loa, se propone que la emergencia de complejidad y jerarquización, al interior de la Tradición del Desierto, se fundamentó en el tráfico exterior de bienes de estatus costeros y mine- 
ros, independientes de la menguada producción agropecuaria, generando riqueza local y consolidación de jefaturas. Hacia estos distritos mineros prestigiosos accedió el régimen incaico a través de alianzas locales, para organizar directamente las mitas enviadas a los campamentos ubicados junto a los afloramientos cercanos o alejados de los locis aldeanos y del Camino del Inca.

La atracción minera de las menas circumpuneñas ejerció el principal motivo para un temprano acercamiento de la expansión inca sobre distritos mineralizados sometidos previamente a una alta producción y especialización. Estos fueron incorporados bajo un dominio político y económico directo, independiente de la circulación de bienes culturales cuzqueños y fuerza de trabajo foráneo, considerados innecesarios de acuerdo a la complejidad sociocultural y económica local.

Para los efectos de documentar preliminarmente nuevas evidencias relacionadas con sitios y rutas vinculadas con labores mineras extractivas se presentaron los distritos del Abra y ChuquicamataTomic. Su locación en espacios inhóspitos y ale- jados de las cabeceras aldeanas indican la aplicación de políticas expansivas locales intervenidas y perfeccionadas por los incas. Visto el poder inca desde las minas del Abra se puede ratificar los enunciados de un dominio político y económico ejercido desde el Alto Loa. La pervivencia de las labores de extracción y fundido en Conchi Viejo, además de labores de fundido y orfebrería de Beter, son indicadores consistentes de que en ambas cuencas se reconoció un prestigio minero-metalúrgico local, esta vez reactivados bajo el régimen español.

\section{Agradecimientos}

El autor agradece la autorización del Dr. C. Morris, Director del Museo Americano de Historia Natural de New York, para publicar las fotos de la Colección Hombre de Cobre. Al colega M. Uribe por involucrarme en esta importante reunión. A Geotécnica Ltda. por invitarme al Proyecto de Impacto Ambiental en Mina R. Tomic y El Abra, oportunidad en que fuimos asistido con suma cordialidad. A la colega C. Agüero, quien sintetizó mejor el presente manuscrito.

\section{BIBLIOGRAFIA}

\begin{abstract}
ACOSTA, J. DE Historia natural y moral de las Indias. 1962 [1591] Fondo de Cultura Económica, México.
AGÜERO, C., M. URIBE, P. AYALA y B. CASES. Variabili- 1997 dad textil durante el Periodo Interme- dio Tardío en el Valle de Quillagua: Una aproximación a la etnicidad. Estudios Atacameños 14: 263-290, San Pedro de Atacama.

ALBECK M. E, S. DIP y M. A. ZABURLIN. Etnicidad y ar1999 quitectura doméstica en Casabindo. Actas XII Congreso Nacional de Arqueología Argentina, Tomo II, pp. 221-220, La Plata.

ALDUNATE, C. y V. CASTRO. Las chullpas de Toconce y 1996 su relación en el Loa Superior. Período Tardío. Editorial Kultrun Ltda., Santiago.

ALDUNATE, C., J. BERENGUER, V. CASTRO, L. CORNE1996 JO, J. MARTÍNEZ y C. SINCLAIRE. Cronología y asentamiento en la región del Loa Superior. Universidad de Chile, Santiago.
ANGIORAMA, C.I. La metalurgia prehispánica en la 1999 quebrada de Humahuaca (Prov. de Jujuy, Argentina). Tesis de Maestría en Arqueología Social de Iberoamérica, Universidad Internacional de Andalucía.

ARRIAZA, B. Paleo-salud de los habitantes de Coyo1990 Ms Oriental: San Pedro de Atacama. Manuscrito NEH Final Report, Washington D.C.

BARBA, A. $\quad$ El arte de los metales. Santiago. 1877

BERENGUER, J. Asentamientos, caravanas y tráfico de 1994 larga distancia en el Norte de Chile: El caso de Santa Bárbara. En Taller de Costa a Selva, pp. 17-46. M. E. Albeck (Ed.). Instituto de Tilcara, Universidad de Buenos Aires.

BURGER, R.L. y R. E. GORDON. Early central andean me1998 tal working from Mina Pérdida, Perú. Science, Vol. 282: 1108-1111. 
BIRD, J. 1977

1979

El Hombre de Cobre, un minero prehistórico del Norte de Chile y sus herramientas. Boletín Museo Arqueológico de La Serena 16: 77-106.

The "Copper Man": A prehistoric miner and his tools from northern Chile. PreColumbian metallurgy of South America. E.P. Benson (Ed.), pp. 105 131. Washington D.C.

BOMAN, E. Antigüedades de la región andina de 1908 la República Argentina y del desierto de Atacama, Vol. I y II. Universidad Nacional de Jujuy.

BROWN, K. y A. CRAIG. Silver mining at Huantajaya,vice1994 royalty of Peru. En Quest of mineral wealth. Aboriginal and colonial mining and metallurgy in Spanish America, pp. 302-327, A. Craig y R. Quest, (Eds.) Louisiana State University, Baton.

BROWMAN, D.L. The dynamic of the Chiripa polity. $1991 \mathrm{Ms} \quad$ Ponencia presentada en el IV Congreso Internacional de Americanistas, New Orleans.

BRUMFIELD, E. Factional competition in complex so1995 ciety, pp. 127-137, D. Miller, M. Rowlands y C. Tilley (Eds.). Routledge. London.

CASTRO, V. Nuevos registros de la presencia inka en 1992 - la provincia del Loa, Chile. Gaceta Arqueológica Andina Vol. VI, 21: 139154, Lima.

CASTRO, V. y V. VARELA. Los caminos del Reinka en la 2000 Región del Loa Superior. Desde la etnografía a la arqueología. XIV Congreso Nacional de Arqueología Chilena, pp. 815-840, Copiapó.

CLARK J, y W. PARRY. Crafts specialization and cultural 1991 complexity. Research in Economic Anthropology 12: 289-346, JAI Press, Greenwich.

CIEZA DE LEON P. Crónica del Perú. Biblioteca de 1947 [1553] Autores Españoles.

$\mathrm{COBO}, \mathrm{B}$. 1964 [1653]

Historia del Nuevo Mundo. Biblioteca de Autores Españoles, T. XCII, Ediciones Atlas, Madrid.

CORNEJO, L. El inka en la región del río Loa: Lo lo1995 cal y lo foráneo. En Hombre y Desierto 9: 203-212, Antofagasta.

COSTA, M.A. y A. LLAGOSTERA. Coyo-3: Momentos fi1994 nales del Periodo Medio en San Pedro de Atacama. Estudios Atacameños 11:
73-108, San Pedro de Atacama.

CRAIG, A. y R. WEST. Quest of mineral wealth aboriginal 1994 and colonial mining and metallurgy in Spanish America. Eds. Baton Rouge. Dep. of Geography and Anthropology, Lousiana State University.

CHILDE, G. Los orígenes de la civilización. Fondo 1954 de Cultura Económica, México.

ELERA, C. y J. PINILLA. Research summary of the Proyecto 1990 Arqueológico Puémape (1987-1989). Willay 34: 2-4, Cambridge.

D'ORBIGNY, A. Viaje a la América Meridional. Bue$1976[1830]$ nos Aires.

ESPINOZA, W. Las llactas en el imperio de los Inkas. 1997 XI Congreso Peruano del Hombre y la Cultura Andina. H. Amat y L. Guzmán (Eds.), pp. 362-374.

FOSTER, G. Copper and copper alloys in ancient 1962 Argentina. Chymia: Annual studies in the history Of chemistry 8: 21-311, University of Pennsylvania Press.

GALLARDO, F., M. URIBE y P. AYALA. Arquitectura inka 1995 y poder en el Pukara de Turi, norte de Chile. Gaceta Arqueológica Andina 24: 151-171, INDEA, Lima.

GARCILASO DE LA VEGA, I. Comentarios reales: El ori1968 [1609] gen de los incas. Editorial Bruguera, Barcelona.

GONZALEZ, A.R. Pre-Columbian metallurgy Argentina: 1979 Historical development and cultural process. En Pre-Columbian metallurgy of South America, E. Benson (Ed.), pp. 133-202. Dumbarton Oaks, Washington D.C.

1983 Inka settlement patterns in a marginal province of the empire: Sociocultural implications. En Prehistoric settlement patterns: Essays in honor of Gordon R. Willey, Evon Vogt (Ed.), pp. $337-$ 360. Albuquerque, N.M. and Cambridge, Mass.: University of New Mexico Press and Harvard University, Peabody Museum of Archaeology and Ethnology.

1992 La metalurgia precolombina de Sudamérica y la búsqueda de los mecanismos de la evolución cultural. En Prehistoria sudamericana: Nuevas perspectivas, B. Meggers (Ed.), pp. 35-44. Taraxacum. Washington D.C.

1992a Las placas metálicas de los Andes del Sur. Contribución al estudio de las religiones precolombinas. Ed. Verlag 
Philipp von Zabern Mainz am Thein, Alemania.

GONZALEZ, L.R. Recursos y organización de la produc1995 ción metalúrgica prehispánica en la región Centro-Sur andino. Un caso de estudio. Actas del XIII Congreso Nacional de Arqueología Chilena. pp. 106125, Antofagasta.

GONZALEZ, L. R. Tecnología y dinámica social. La pro2000 ducción metalúrgica prehispánica en el noroeste argentino. Tesis Doctoral, Facultad de Filosofía y Letras, Universidad de Buenos Aires.

GONZALEZ, L. R. y T. PALACIOS. El volar es para los pá1996 jaros. Análisis técnicos de dos piezas metálicas procedentes del valle de Santa María, Provincia de Catamarca. Arqueología 6: 25-46. Instituto de Ciencias de Antropológicas, Buenos Aires.

GRAFFAM, G.. M. RIVERA y A. CAREVIC. Cooper smelting 1994 in the Atacama: Ancient metallurgy at the Ramaditas site, Northern Chile. Quest of mineral wealth: Aboriginal and colonial mining and metallurgy in Spanish America. A.K. Craig y R. West, (Eds.) Geosciences and Man Vol. 33: 75-92. Dep. of Geography y Anthropology, Louisiana State University Baton Rouge.

GRAFFAM, G. Proyecto Metalurgia Atacameña, Infor$1996 \mathrm{Ms}$ me de avance.

HARRIS O. y T. BOUYSSE-CASSAGNE. América y el 1988 Mundo Aymara, pp. 217-275, Compilador X. Albó, UNESCO-Alianza, Madrid.

HIDALGO, J. Las culturas protohistóricas del Nor1971 te de Chile. El testimonio de los cronistas. Memoria de Título, Depto. de Historia y Geografía, Universidad de Chile, Santiago de Chile.

IRIBARREN, J. Una mina de explotación inkaica: EI Sal1971 vador, Provincia de Atacama. Boletín de Prehistoria y Actas del VI Congreso de Arqueología Chilena, pp. 267-284, Universidad de Chile.

KRAPOVICKAS, P. Nuevos fechados radiocarbónicos para 1987 el sector oriental de la Puna y la quebrada de Humahuaca. Runa XVI1XVIII: 207-219, Buenos Aires.

1968 Subárea de la Puna Argentina. Actas y Memorias del XXXVII Congreso Internacional de Americanistas. Vol. 2, pp. 235-271, Buenos Aires.
1958-9 Un taller lapidario en el Pukara de Tilcara. Runa IX: 137-151, Buenos Aires.

LATCHAM, R. A rqueología de la región atacameña. 1938 Prensas de la Universidad de Chile, Santiago.

LECHTMAN, H. A metallurgical site survey in the Peru1976 vian Andes. Journal of Field Archaeology $3(3): 1-41$.

1979 Issues in Andean metallurgy. En PreColumbian metallurgy of South America, E.P. Benson (Ed.), pp. 1-40. Dumbarton Oaks, Washington, DC.

1980 The Central Andes: Metallurgy without iron. En The coming of the age of iron. T.A. Wertime y J.D. Muhly, (Eds.), pp. 269-334. Yale University Press, New Heaven.

1981 Copper-arsenic bronzes from the north coast of Peru. Annals of the New York Academy of Sciences 376: 77-122.

1984 Pre-Columbian surface metallurgy. Scientific American 250(6): 56-63.

1988 Reflexiones sobre la metalurgia de América. Arqueología de las Américas 45, Congreso Internacional de Americanistas, pp. 301-306, Bogotá.

1997 El bronce arsenical y el Horizonte Medio. En Arqueología, Antropología e Historia en los Andes. Homenaje a M. Rostworoski. R. Varón y J. Flores (Eds.) pp. 153-186, Instituto de Estudios Peruanos, Lima.

LECHTMAN, H. y A.R. GONZALEZ. Análisis técnico de 1991 una campana de bronce estañífero de la Cultura Santa María, Noreste Argentino. Boletín del Museo Chileno de Arte Precolombino 5:81-86, Santiago de Chile.

LE PAIGE, G., Notas manuscritas (Biblioteca IIAMMs. UCN).

LYNCH, T. Tambo Inkaiko Catarpe - Este (informe 1978 de avance) Estudios Atacameños 5: 142-147, San Pedro de Atacama.

LYNCH, T. y L. NUÑEZ. Nuevas evidencias inkas entre Ko1994 llahuasi y Río Frío (I y II Regiones del Norte de Chile) Estudios Atacameños 11:145-164, San Pedro de Atacama.

LOZANO MACHUCA. Carta del Factor de Potosí Lozano 1992 [1586] Machuca en que da cuenta de cosas de aquella villa y de las minas de los Lípez. 
Estudios Atacameños 10: 30-34, San Pedro de Atacama.

LLAGOSTERA, A. Hipótesis sobre la expansión inkaica en 1976 la vertiente occidental de los Andes Meridionales. Homenaje al Dr. Gustavo Le Paige S. J., Universidad Católica del Norte, Antofagasta.

MARQUET, P.A., F. BOZINOVIC, G. A. BRATSHAW, C. 1998 CORNELIUS, H. GONZALEZ, J. R. GUTIERREZ, E. HAJEK, J.A. LAGOS, F. LOPEZ-CORTES, L. NUÑEZ, E. F. ROSELLOT, C. SANTORO. H. SAMANIEGO, V. G. STANDEN, J. C. TORRES-MURA y F. M. YAKSIC. Ecosistema del desierto de Atacama y Area Andina adyacente. Revista Chilena de Historia Natural, vol. 71, 4: 593-617.

MURPHY, M., S. AGUILERA, L. NUÑEZ, F. TELLEZ, H. $1999 \mathrm{Ms}$ CARCAMO. V. CONEJEROS: $\mathrm{M}$. CARAVAGLIA, G. ALVAREZ, A.R. GONZALEZ y M. BALDINI. Estudio de la Colección de Metales Precolombinos en el norte de Chile y noroeste de Argentina (Proyecto Binacional C13413/6 Fundación Antorcha).

MURRA, J. Formaciones económicas y políticas 1978 del mundo andino. Instituto de Estudios Andinos, Lima.

NIELSEN A. Tráfico de caravanas en el sur de Boli1997-98 via: Observaciones etnográficas e implicancias arqueológicas. Relaciones, Sociedad Argentina de Antropología XXIl-XXIII, pp. 139-178, Buenos Aires.

$1999 \mathrm{Ms}$ Ethnoarchaeological perspective on Caravan trade in the South Central Andes. Manuscrito en poder del autor.

NIEMEYER, H. y M. RIVERA. El camino del inka en el des 1983 poblado de Atacama. Boletín de Prehistoria de Chile 9: 91-193, Santiago.

NUNEEZ. L. L'evolution millenaire d'une vallée: 1978 Peuplement et resources a Tarapacá. Annales 5-6: 906-920, París.

Tráfico de metales en el área Centro-Sur andino: Factos y expectativas. Cuadernos del Instituto Nacional de Antropología 12: 73-105, Buenos Aires.

1992 Emergencia de complejidad y arquitectura jerarquizada en la Puna de Atacama: Las evidencias del sitio Tulán-54. En Taller de Costa a Selva. M.E. Albeck, (Ed.) Instituto Interdisciplinario
Tilcara, pp. 85-115, Tilcara.

1994 Ms Un señor Yavi en el ayllo de Conde Duque. (San Pedro de Atacama). Manuscrito en poder del autor.

1994

Cruzando la cordillera por el norte: Señoríos, caravanas y alianzas. En la cordillera de los andes: Ruta de encuentros, pp. 9-22. Museo Chileno de Arte Precolombino, Santiago.

1995 Evolución de la ocupación y organización del espacio atacameño. En Agua, ocupación del espacio y economía campesina en la región atacameña. $P$. Pourrut y L. Núñez (Eds.) pp. 18-29, Orstom-Universidad Católica del Norte, Antofagasta.

$1997 \mathrm{Ms} \quad$ Informe de impacto ambiental arqueológico (Proyecto Kollahuasi). Informe presentado a Geotécnica Ltda.

1998 Ms-a Informe de impacto ambiental arqueológico (Proyecto Abra). Informe presentado a Geotécnica Ltda.

1998 Ms-b Impacto ambiental arqueológico (Proyecto tendido eléctrico Abra). Informe presentado a Geotécnica Ltda. (Manuscrito).

$1999 \mathrm{Ms}$ Informe de impacto ambiental arqueológico (Proyecto Tomic) Informe presentado a Geotécnica Ltda.

NUÑEZ, L. y T. DILLEHAY. Movilidad giratoria, armo1979 nía social y desarrollo en los Andes Meridionales: Patrones de tráfico e interacción económica. Universidad del Norte, Antofagasta

NUÑEZ, L., I. CARTAJENA, J.P. LOO, S. RAMOS, T. CRUZ, 1997 T. CRUZ y H. RAMIREZ. Registro e investigación del arte rupestre en la cuenca de Atacama. (Informe preliminar). Estudios Atacameños 14: 307 325. San Pedro de Atacama.

PONCE, C. Las Culturas Wankarani y Chiripa y 1970 su relación con Tiwanaku. Ed. Los Amigos del Libro, La Paz.

RAFFINO, R. La ocupación inka en el NO Argentino: 1978 actualización y perspectivas. Relaciones de la Sociedad Argentina de Antropología XII: 95-121, Buenos Aires.

1981 Los Incas del Kollasuyu. Editorial Ramos Americana, La Plata.

REGALADO DE HURTADO, L. Control de excedentes y pro1997 ceso sucesorio en el período inkaiko: 
Álgunos aspectos relacionados con la organización política. En Arqueología, antropología e historia. Homenaje a M. Rostworowski. R. Varon e I. Flores. (Eds.), pp. 321-334. IEP, Lima.

REES CH. y P. DE SOUZA. Procesos de producción lítica $2000 \mathrm{Ms}$ durante el Período Formativo en la Subregión del río Salado (II Región, norte de Chile). Ponencia presentada en Congreso de Arqueología Chilena, Arica

SHIMADA, I. Aboriginal and colonial mining and me1994 tallurgy in spanish America. En Quest of Mineral Wealth, vol. 33. pp. 75-92. A.K. Craig y R.C. West. (Eds.) Geoscience and Man, Baton Rouge.

SHIMADA, I. y J. MERKED. Copper alloy metallurgy in an1991 cient Peru. Scientific American 265: 80-86.

SINCLAIRE, C. Los sitios de "muros y cajas" del río Loa 1994 y su relación con el tráfico de caravanas. En Taller de Costa a Selva. M.E. Albeck, (Ed.), pp. 51-74. Instituto Interdisci-plinario de Tilcara, Tilcara

TARRAGO, M. y L. GONZALEZ. La producción metalúr-
1998 gica prehispánica en el asentamiento de Tilcara (Prov. de Jujuy). Las sociedades locales y sus territorios. B. Cremonte (Ed.), pp. 179-198. Jujuy.

ROWE, J. H. Inka culture and the time of the spanish 1946 conquest. Handbook of South American Indians, 2, J. Steward (Ed.).

TELLEZ, F. y M. CERVELLINO. Investigaciones arqueoló1976 gicas en la Aldea Quillagua-1. Memoria de Título. Departamento de Arqueología, Universidad del Norte, Antofagasta.

TELLEZ, F. Rescate arqueológico de un cementerio 1998 Ms. en el patio de la Casa Parroquial (San Pedro de Atacama). Manuscrito en Biblioteca del I.I.A.M., San Pedro de Atacama.

URIBE, M. La alfarería de Caspana en relación a la 1997 prehistoria tardía del Desierto de Atacama y su relación con la Subárea Circumpuneña. Estudios Atacameños 14: 243-262, San Pedro de Atacama.

1999 La alfarería inka de Caspana (norte de Chile). Boletín de Ia Sociedad Chilena de Arqueología 27: 11-19, Santiago. 


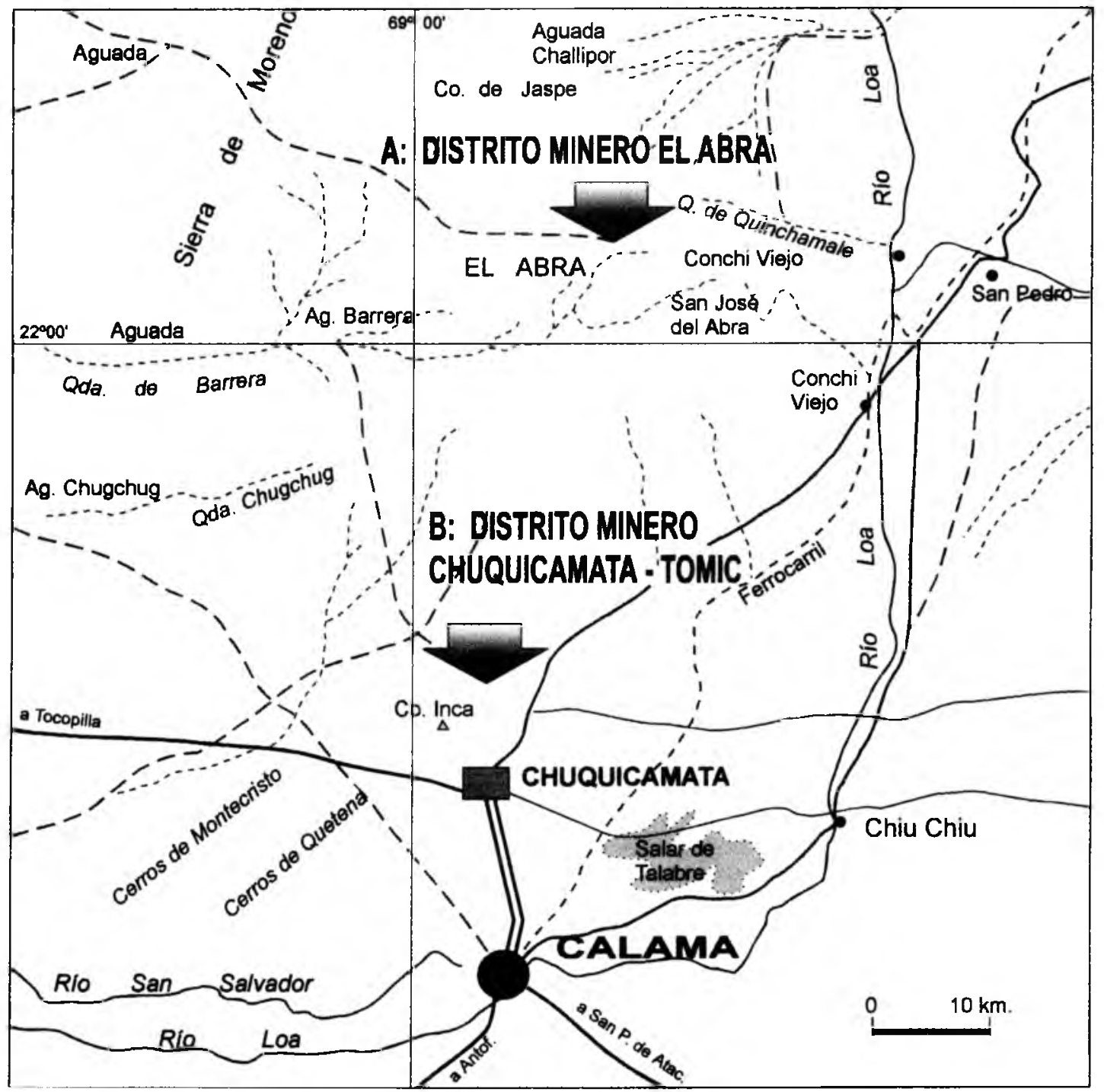

Figura 1. Ubicación de los distritos arqueológicos El Abra (Ab) y Chuquicamata (Chu) 


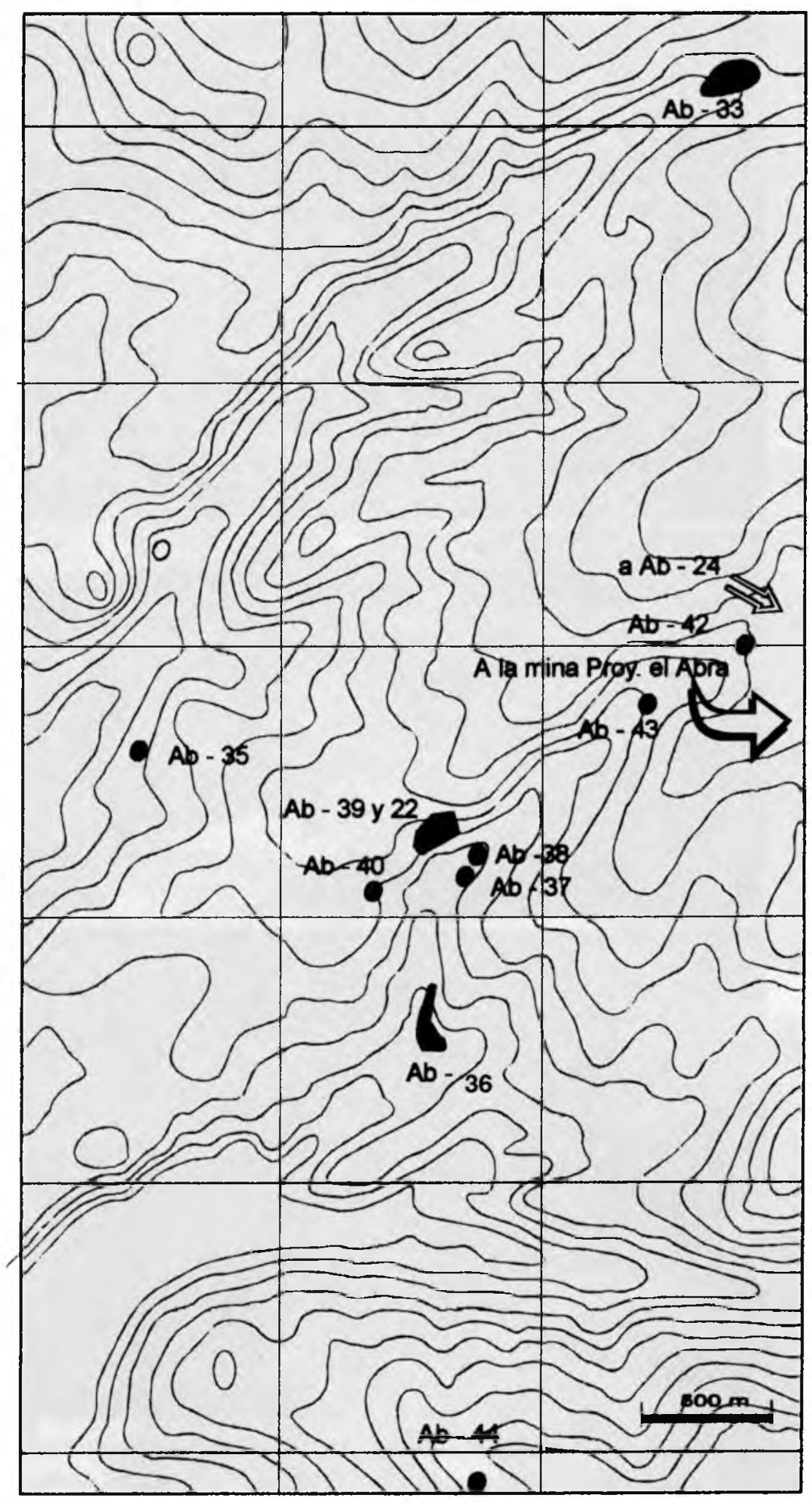

Figura 2. Ubicación de los sitios principales relacionados con las minas prehispánicas del Abra 

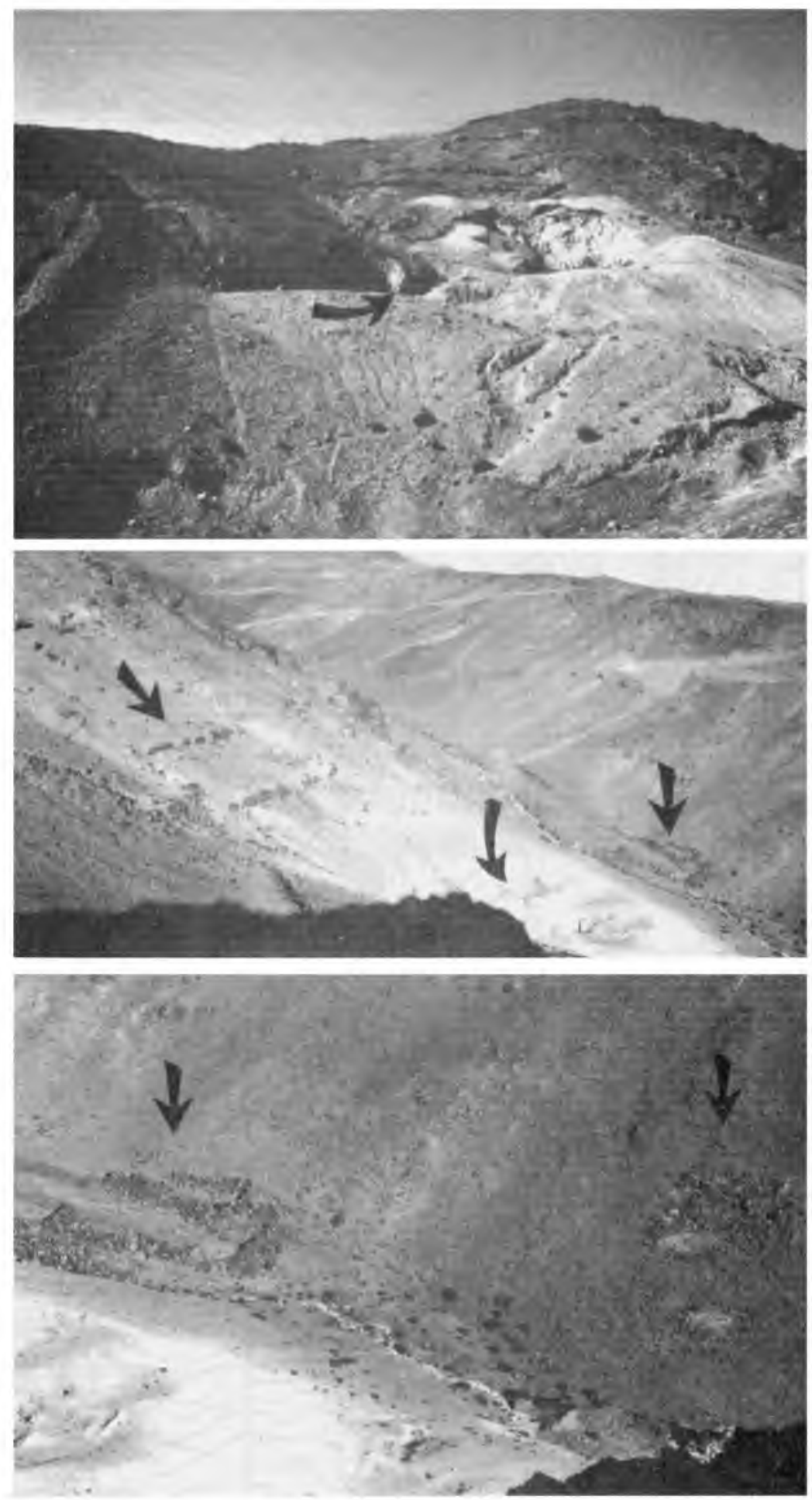

Figura 3. Superior: Panorama de la mina prehispánica Abra (contacto inka-local). La flecha marca el nivel principal de extracción. El material claro corresponde a la carga estéril acumulada en el entorno. Medio: Panorama de la quebrada de Las Ruinas. La flecha izquierda marca los muros de contención sobre la mina. La flecha del centro la gran horadación del proceso de extracción. La flecha derecha indica el campamento Al-38. Inferior: Detalle de los campamentos Ab-38 y 37 

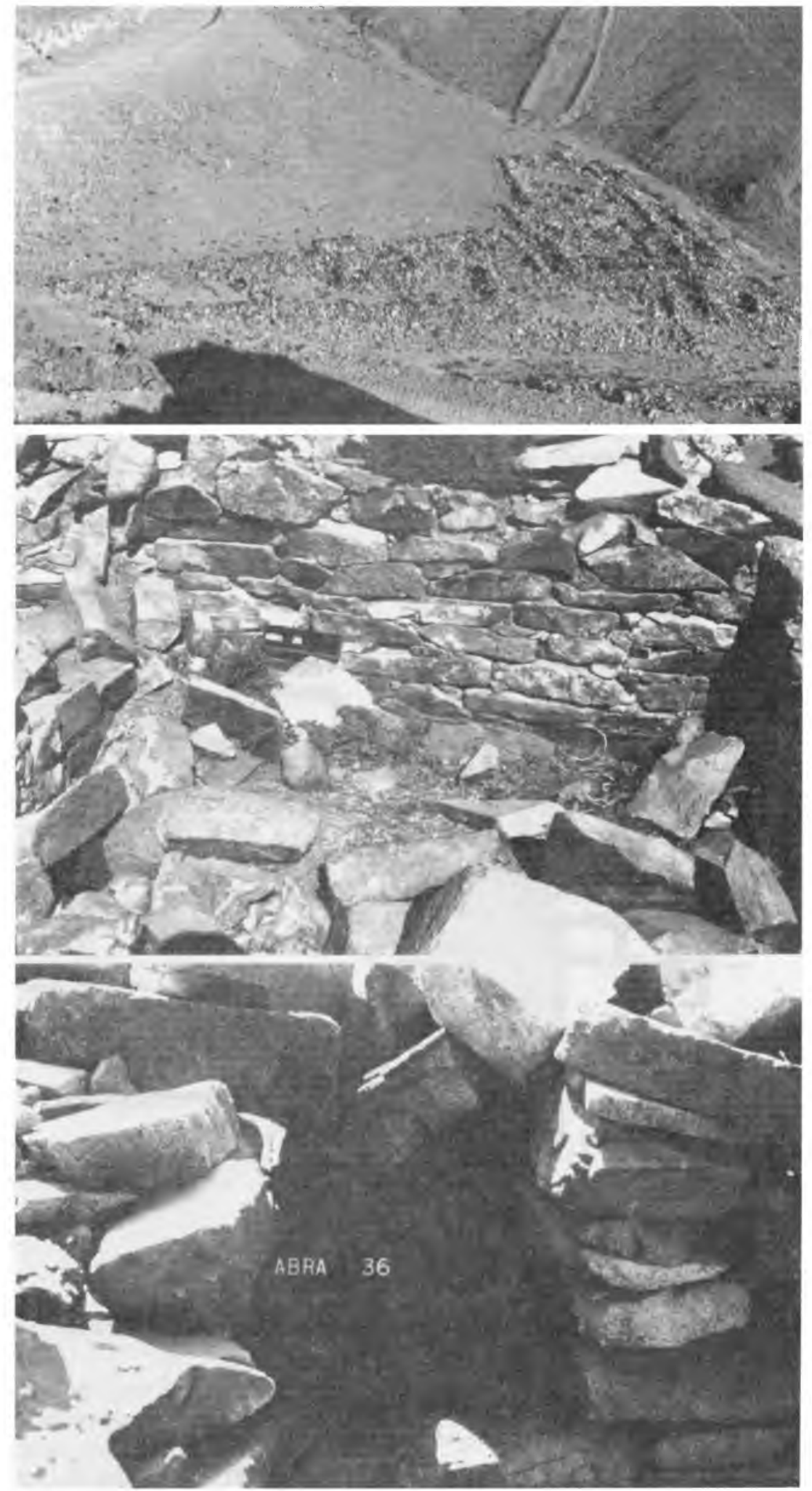

Figura 4. Superior: Panorama del asentamiento Ab-36 (contacto inca-local). Medio: Detalle del muro del depósito jerarquizado. Inferior: Detalle de un nicho trapezoidal del depósito jerarquizado 


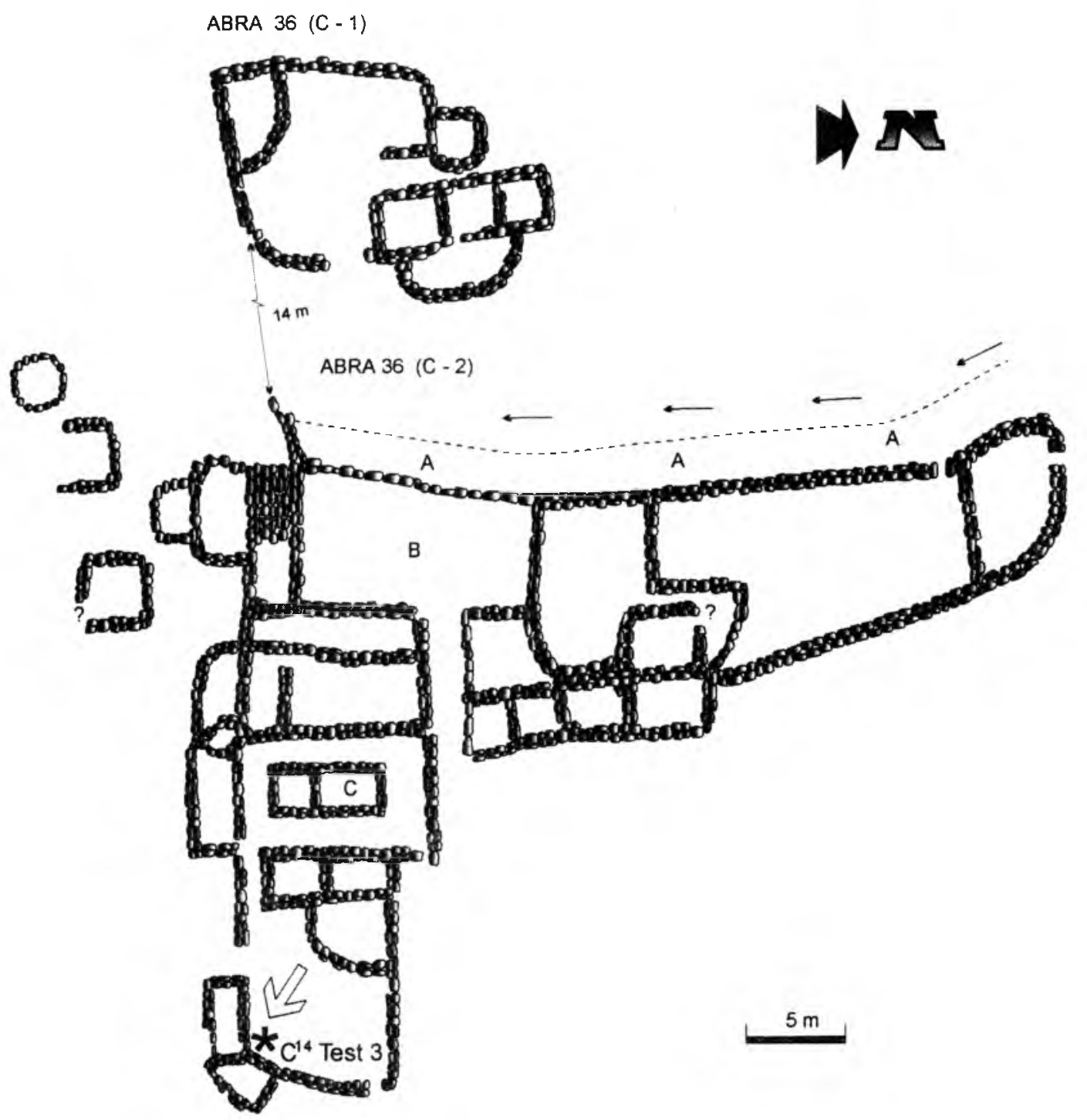

Figura 5. Croquis del asentamiento Abra-36: Ubicación del test $C 14$

$\leftarrow \quad$ Curso inferior de la quebrada

A) Borde inclinado del terraplen artificial empedrado

B) Cancha de percusión de mineral de cobre

C) Bodegas jerarquizadas 


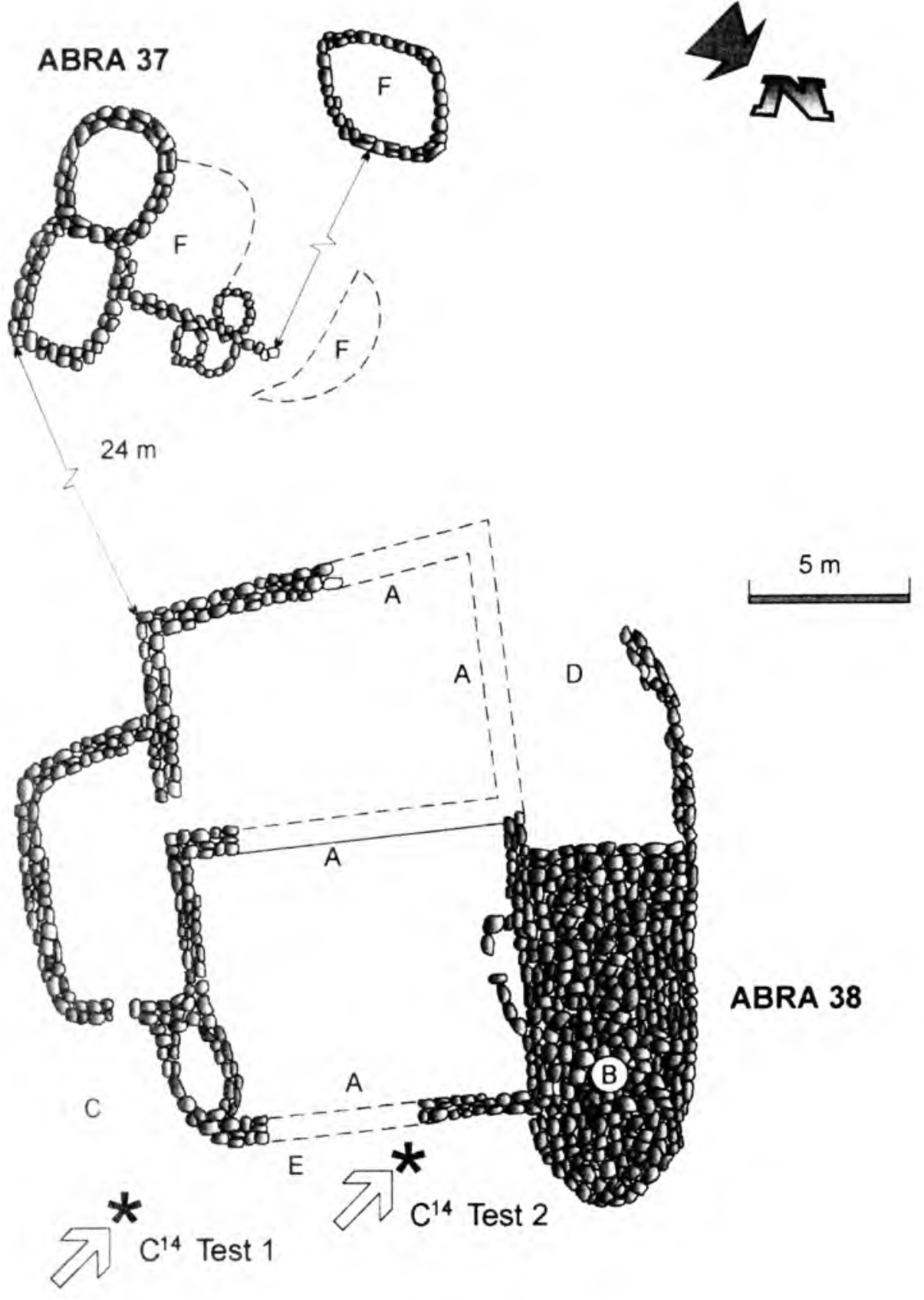

Figura 6. Croquis de los campamentos Abra 37-38 y ubicación de los test C14

A) Muro destruido por entrada de maquinaria pesada

B) Emplantillado de piedras seleccionadas o cancha de separación de estéril de mineral de cobre

C) Concentración de martillos y yunques líticos

D) Depósitos de desperdicios (huesos, fogones y cerámica)

E) Fogones expuestos por maquinaria pesada

F) Concentración de estéril o desechos de ganga de cobre por percusión 

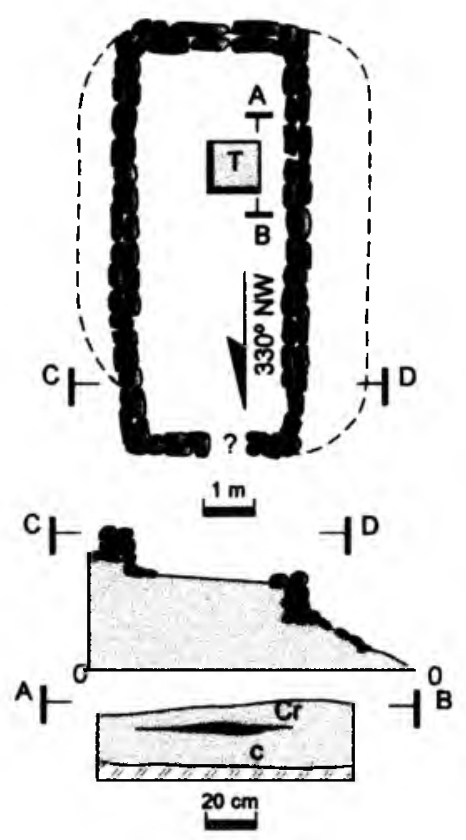

Figura 7. Croquis de la cancha en plataforma Ab-40

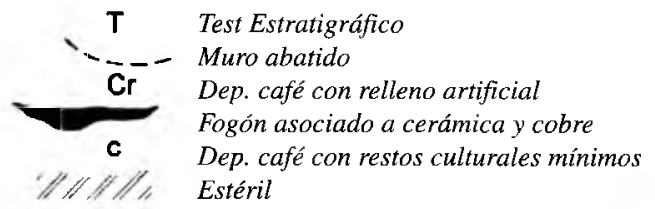

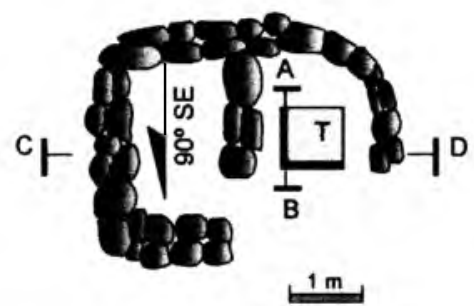
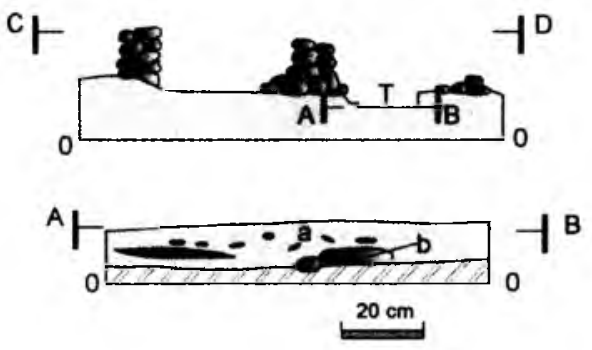

Figura 8. Croquis del campamento de labor Ab-44 (d)

$\begin{array}{ll}\mathrm{T} & \text { Test Estratigráfico } \\ \mathbf{a} & \begin{array}{l}\text { Dep. oscuro con orgánico y cerámica } \\ \mathbf{b}\end{array} \\ \begin{array}{l}\text { Bloques líticos como yunques } \\ \text { Bolsón con ceniza y cerámica } \\ \text { Estéril }\end{array}\end{array}$

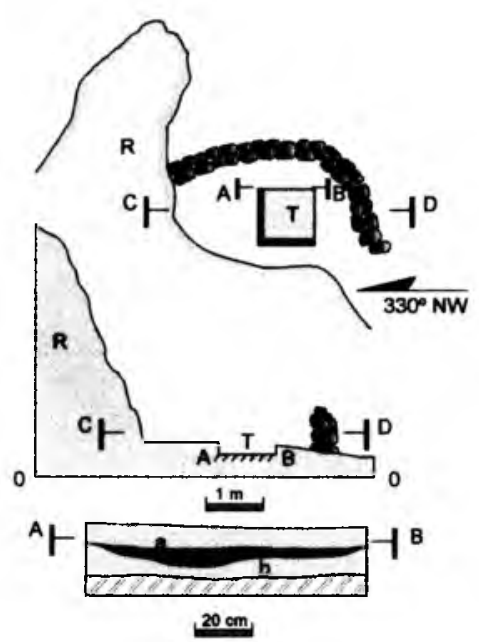

Figura 9. Croquis del campamento de labor Ab-24

$\begin{array}{ll}\mathbf{T} & \begin{array}{l}\text { Test Estratigráfico } \\ \mathbf{R}\end{array} \\ \mathbf{a} & \begin{array}{l}\text { Roca } \\ \text { Dep. café orgánico con cerámica } \\ \text { Fogón con cerámica } \\ \text { Dep. café oscuro orgánico con } \\ \text { carbón y cobre } \\ \text { Estéril }\end{array} \\ \end{array}$




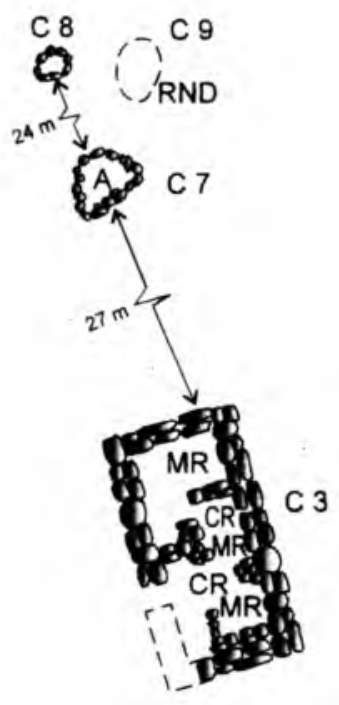

C 6

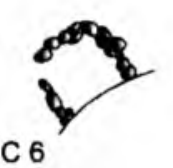

C 4

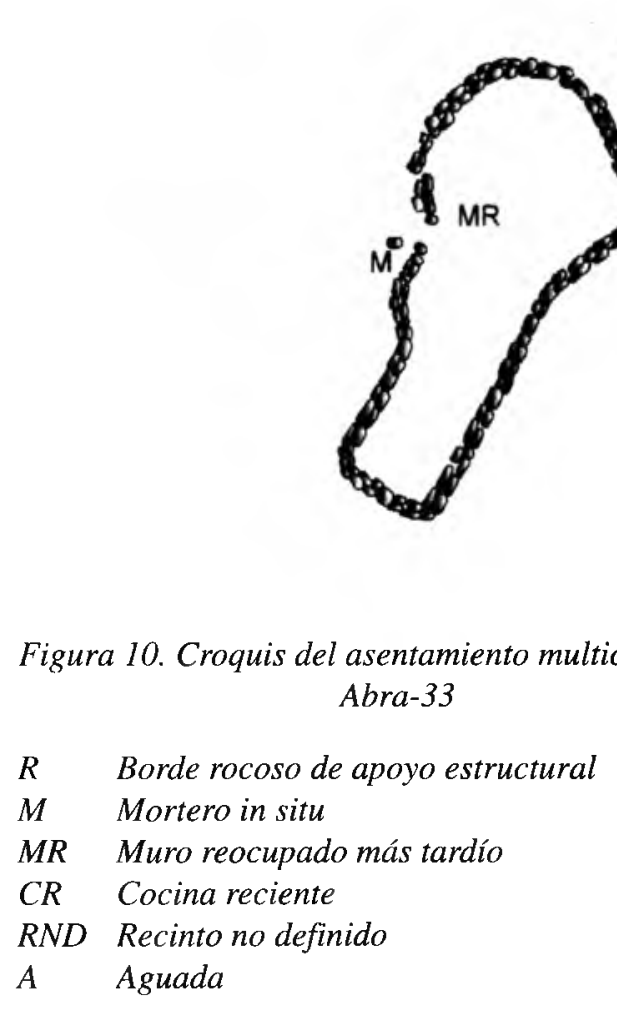

C 2

N

C 1

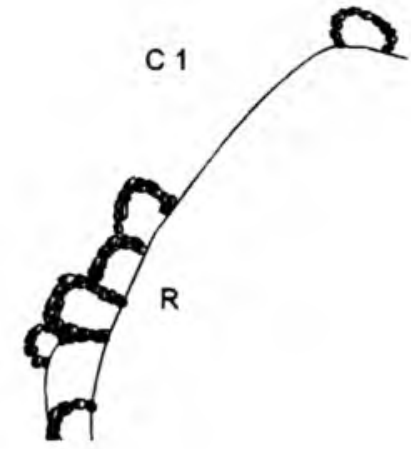



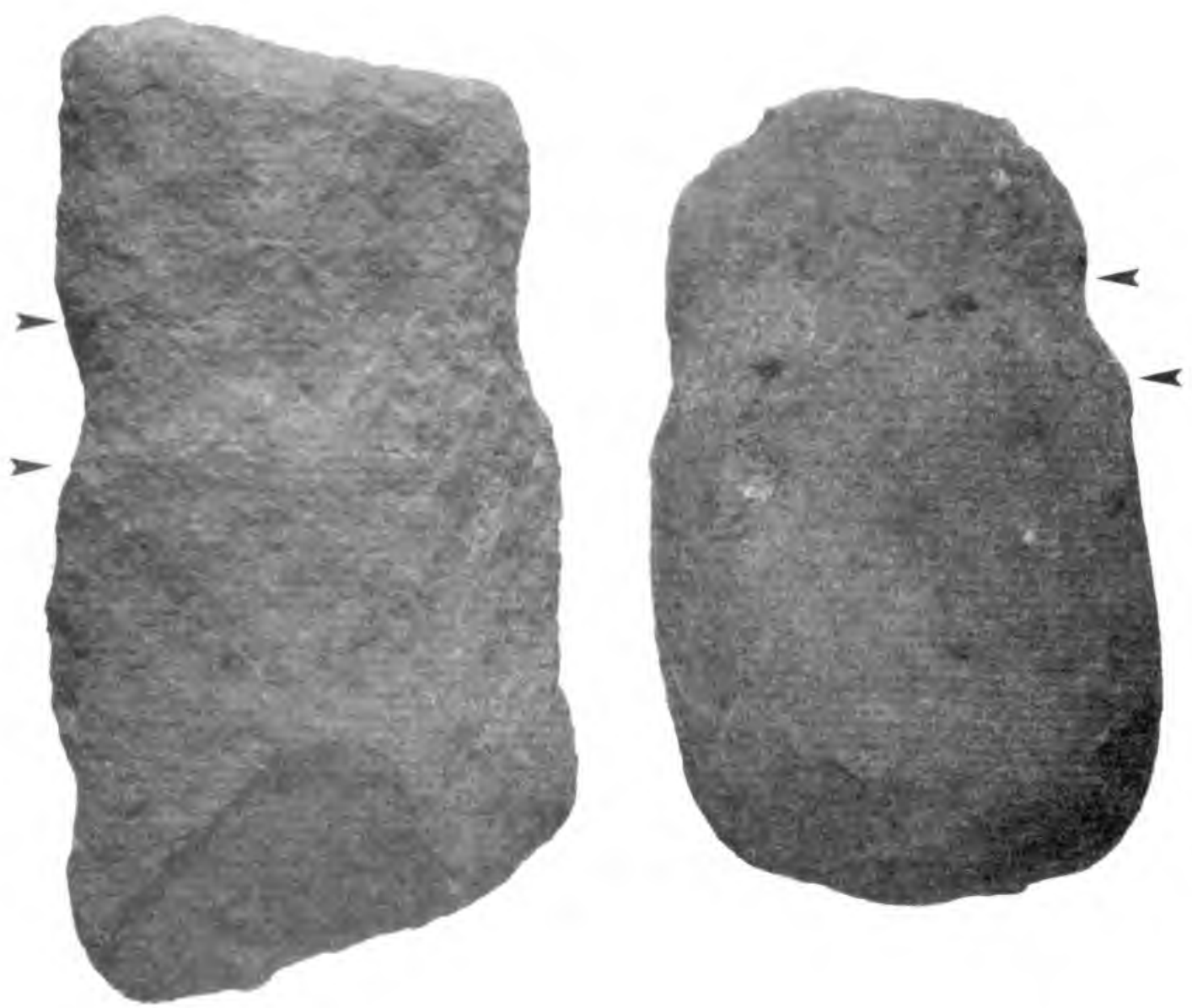

Figura 11. Izquierda: Martillo del sitio Ab-22, sector $3(20 \mathrm{~cm}$ longitud). Derecha: Martillo del sitio Ab-22, sector 5 (16.3 cm longitud). Las flechas marcan el ancho de la escotadura para el paso de las ataduras de cuero 


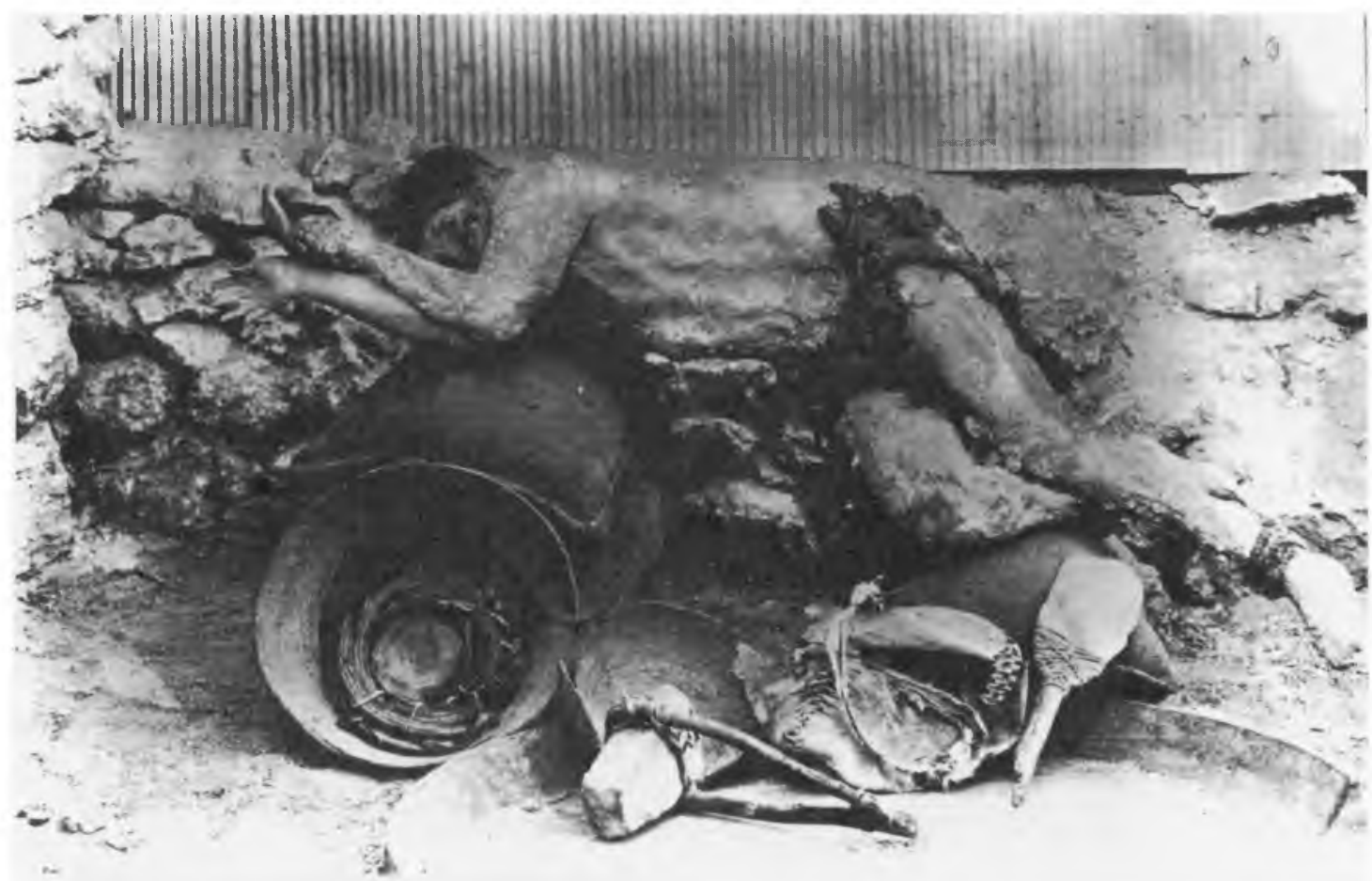

Figura 12. Foto de fines del siglo pasado del llamado "Hombre de Cobre" una vez trasladado a una mina del área de Chuquicamata con sus principales implementos de labor minera, datado por los 500-700 DC (Bird 1979). Foto gentileza del Museo Americano de Historia Natural de New York

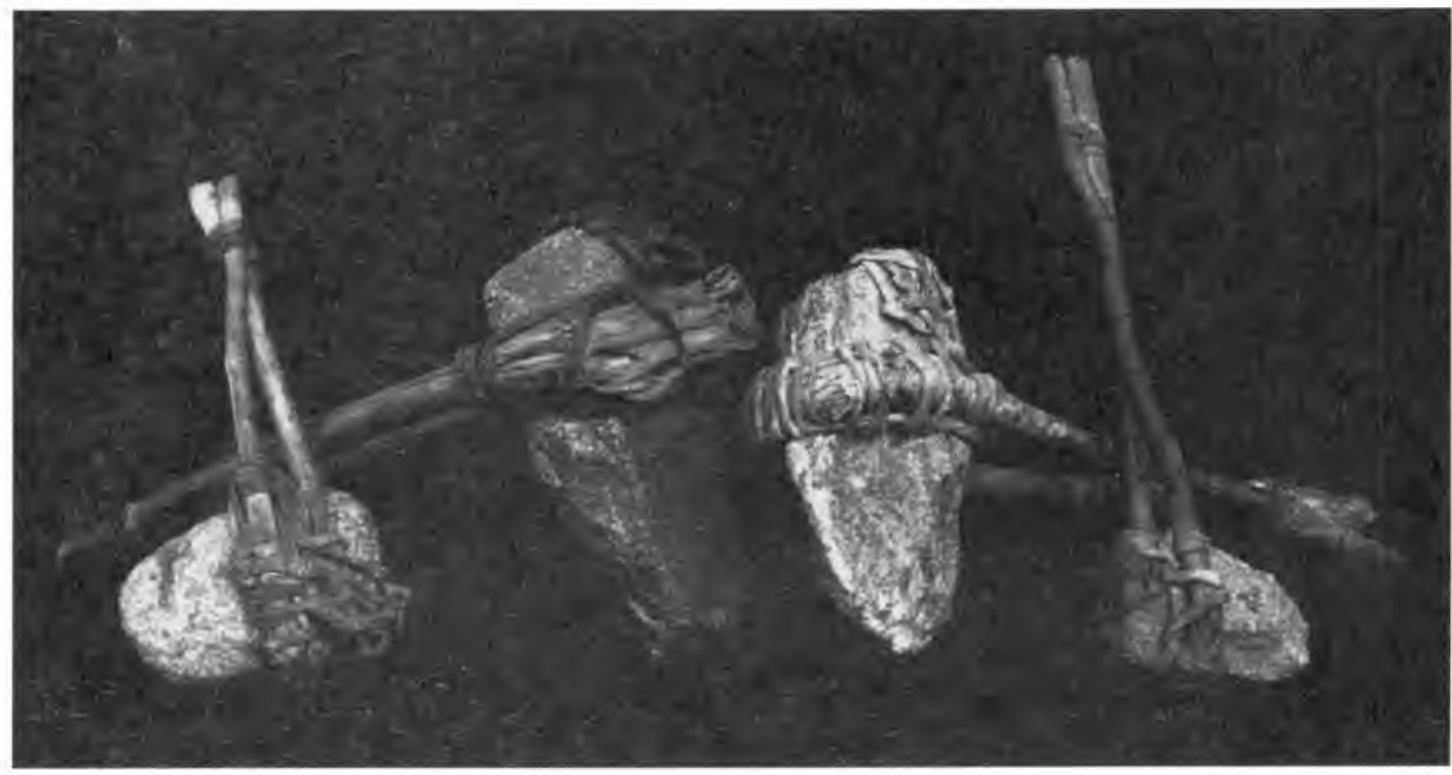

Figura 13. Martillos enmangados con los cuerpos atados con cueros a lo largo de las escotaduras transversales, incluyendo su fijación al extremo proximal, correspondientes a la colección "Hombre de Cobre" datado por los 500-700 DC. Su diversidad tipológica es similar a los registros de la mina prehispánica Abra (contacto inca-local). Foto gentileza del Museo Americano de Historia Natural de New York 

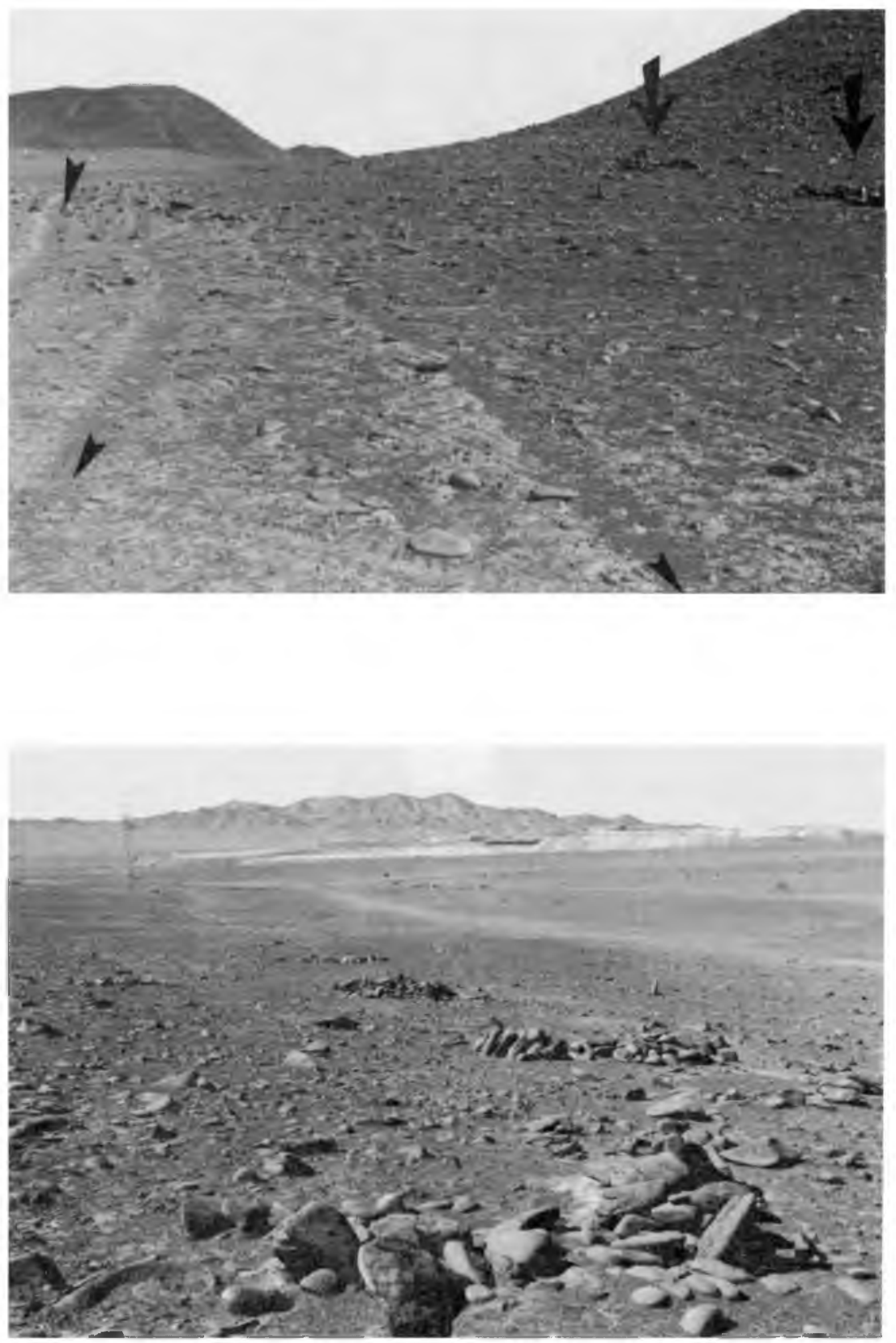

Figura 14. Superior: Ubicación de dos estructuras del campamento Chu-2 (marcadas con flecha) asociado a rutas caravaneras indicadas (flechas en el sector izquierdo). Inferior: Panorama del campamento Chu-2 con los desmontes de la actual mina principal de Chuquicamata en el fondo. La fragmentación de cerámica en recintos y rutas es de data pre inca. 

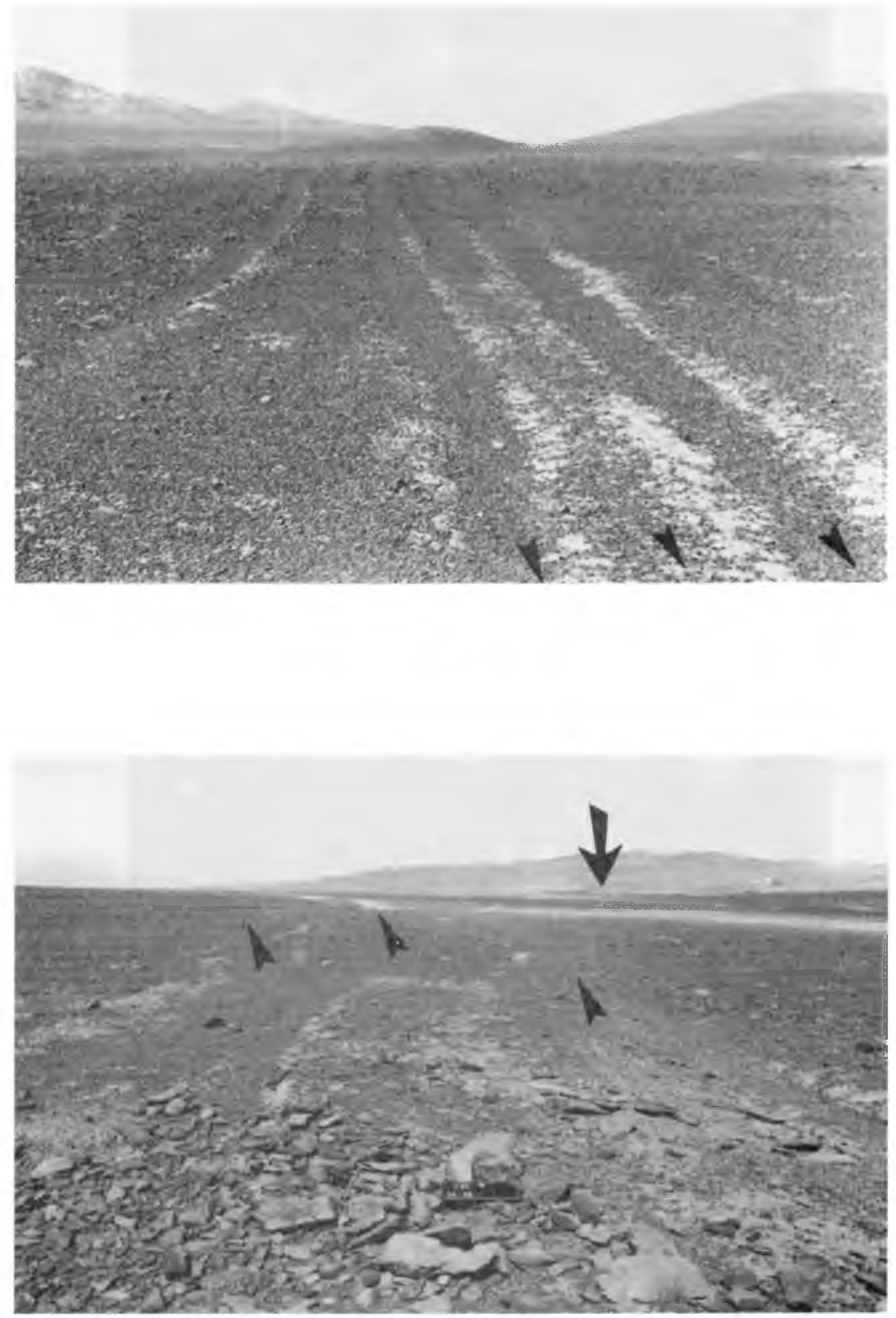

Figura 15. Superior: Rutas caravaneras orientadas al sitio Chu-9 de O a E. Inferior: El sitio Chu-9 con concentración de piedras, fragmentación de cerámica, ofrendas de partículas de turquesa y rutas orientadas a Lasana - Chiu-Chiu de O a E. La flecha al fondo marca el actual Proyecto Tomic 

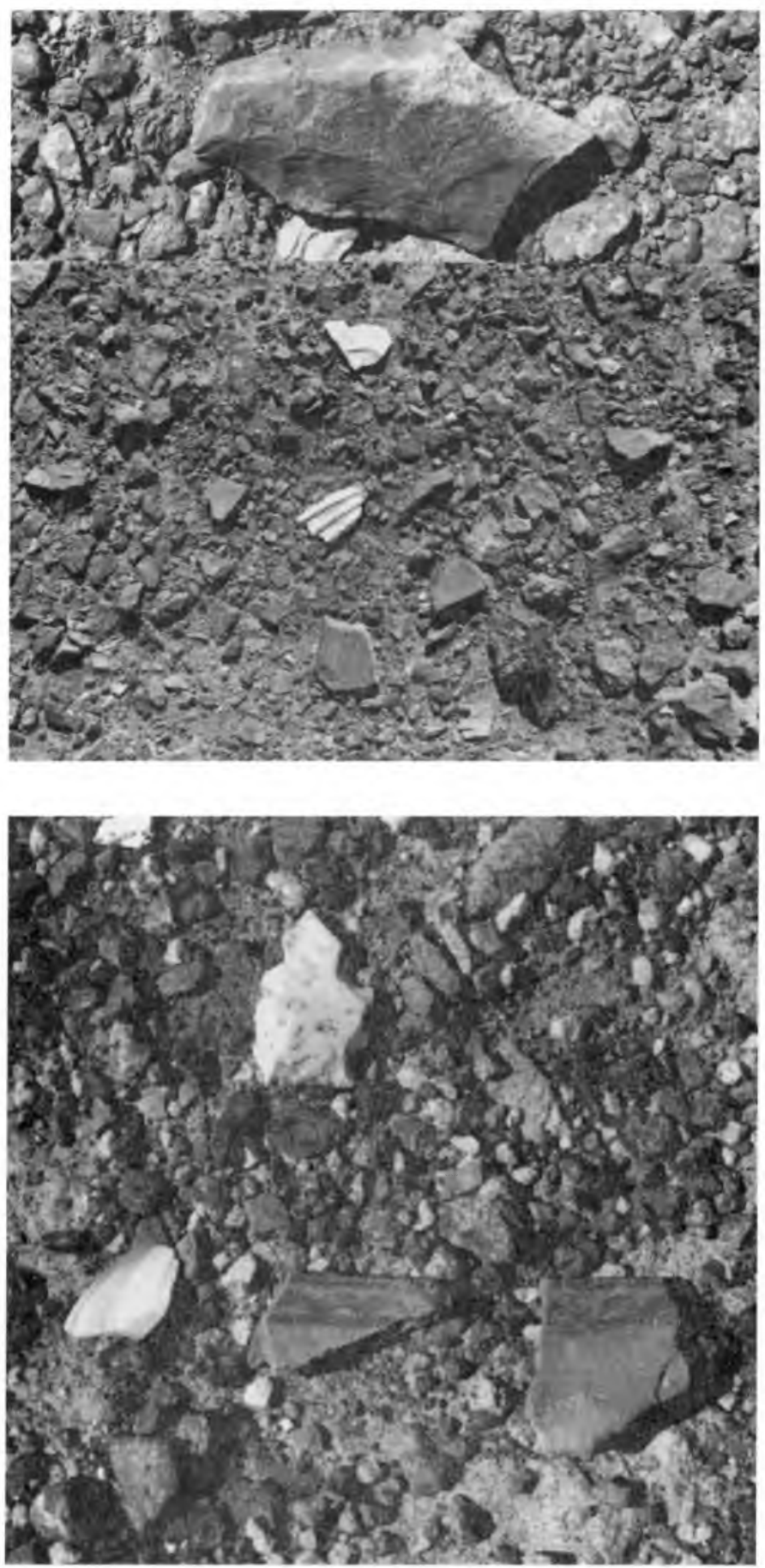

Figura 16. Superior: Rutas del sector Chu-9 con fragmentos de cerámica doméstica pre inca, ostión y martillo (16 cm longitud). Inferior: Sector con ofrendas in situ de partículas de turquesa, concha de almeja, artefacto lítico y dos fragmentos de cerámica Hedionda del Componente Altiplánico pre inca 


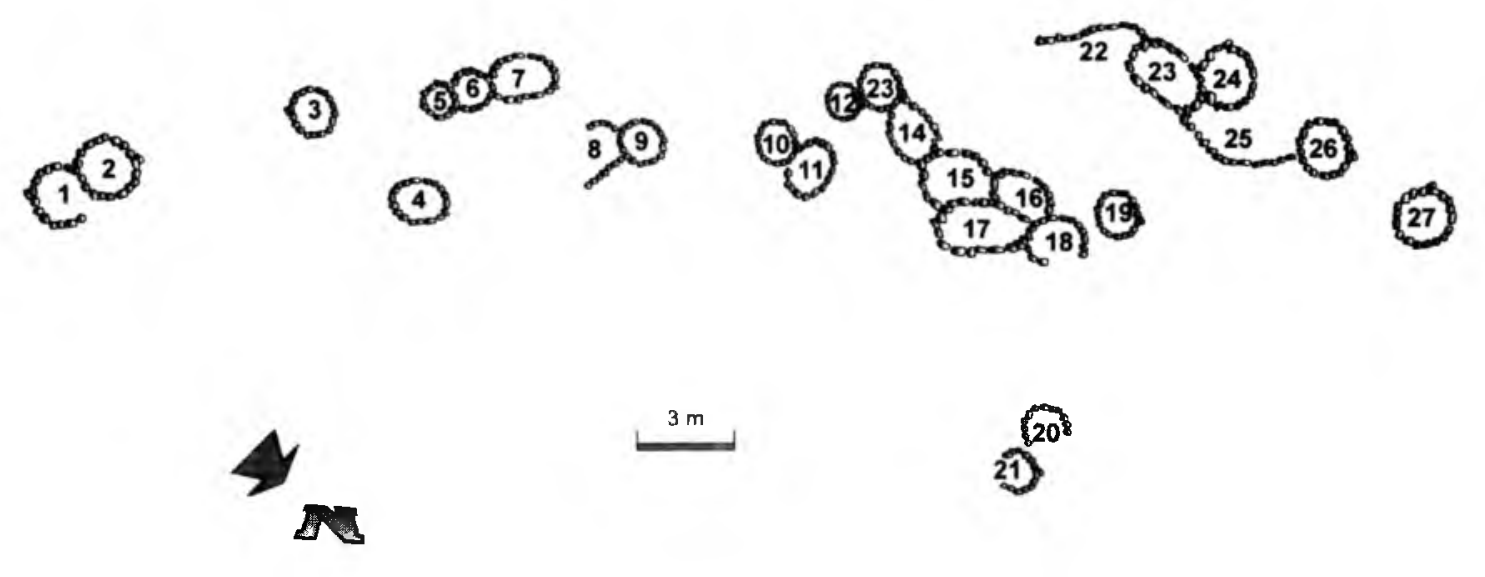

Figura 17. Croquis del asentamiento Chu-5 de data pre inca con reocupaciones prehispánicas e hispánicas, asociado a rutas caravaneras orientadas de las minas al río Loa Medic

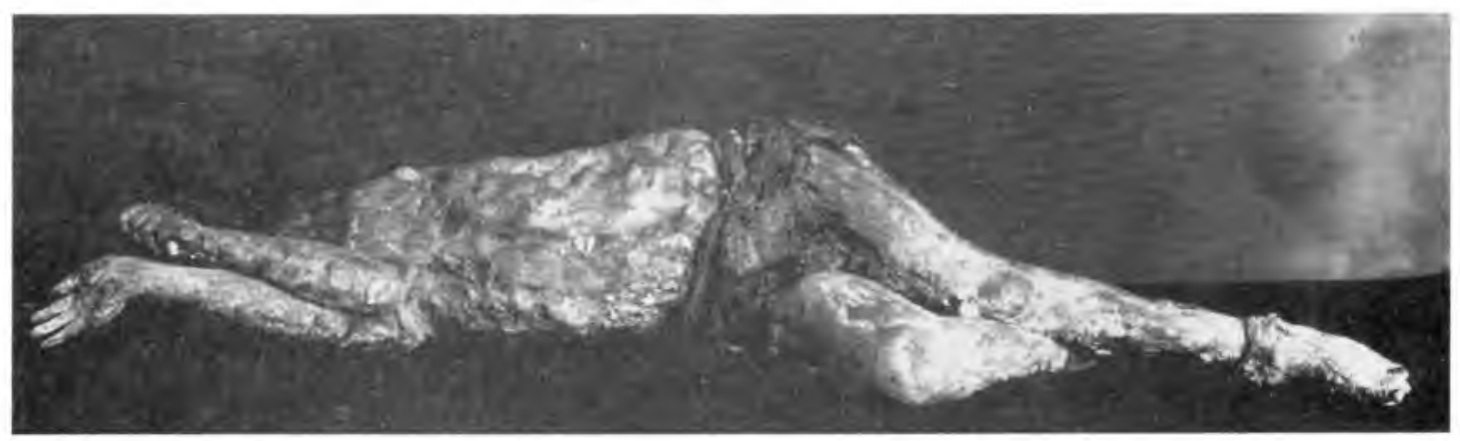

Figura 18. Detalle del joven minero, con cobertura púbica, que formó parte de una colonia pre inca eventualmente enviada a Chuquicamata desde los asentamientos del río Loa Medio-Superior 
